\title{
Carnosine, Small but Mighty-Prospect of Use as Functional Ingredient for Functional Food Formulation
}

\author{
Ivana Jukić ${ }^{1,2}\left(\right.$, Nikolina Kolobarićc ${ }^{1,2}$, Ana Stupin $1,2,3 \oplus$, Anita Matić ${ }^{1,2}$, Nataša Kozina ${ }^{1,2}$, Zrinka Mihaljević $1,2 \oplus$, \\ Martina Mihalj 1,2,4®) Petar Šušnjara ${ }^{1,2}$, Marko Stupin 1,2,5 , Željka Breškić Ćurić 2,6 ${ }^{2}$ Kristina Selthofer-Relatić ${ }^{2,5,7}$, \\ Aleksandar Kibel ${ }^{1,2,5}$, Anamarija Lukinac ${ }^{2,8}$, Luka Kolar ${ }^{2,9}$, Gordana Kralik ${ }^{2,10}$, Zlata Kralik ${ }^{2,11} \mathbb{1}$, \\ Aleksandar Széchenyi ${ }^{2,12}$, Marija Jozanović ${ }^{2,12}$, Olivera Galović ${ }^{2,12}$, Martina Medvidović-Kosanović ${ }^{2,12}$ \\ and Ines Drenjančević $1,2, * \mathbb{D}$
}

Citation: Jukić, I.; Kolobarić, N.; Stupin, A.; Matić, A.; Kozina, N.; Mihaljević, Z.; Mihalj, M.; Šušnjara, P.; Stupin, M.; Ćurić, Ž.B.; et al. Carnosine, Small but Mighty-

Prospect of Use as Functional Ingredient for Functional Food Formulation. Antioxidants 2021, 10, 1037. https://doi.org/10.3390/ antiox10071037

Academic Editors: Esther MolinaMontes and Angela Hernández-Ruiz

Received: 31 May 2021

Accepted: 22 June 2021

Published: 28 June 2021

Publisher's Note: MDPI stays neutral with regard to jurisdictional claims in published maps and institutional affiliations.

Copyright: (c) 2021 by the authors. Licensee MDPI, Basel, Switzerland. This article is an open access article distributed under the terms and conditions of the Creative Commons Attribution (CC BY) license (https:// creativecommons.org/licenses/by/ $4.0 /)$
1 Department of Physiology and Immunology, Faculty of Medicine, Josip Juraj Strossmayer University of Osijek, J. Huttlera 4, HR-31000 Osijek, Croatia; ivana.jukic@mefos.hr (I.J.); nikolina.bilic.dujmusic@gmail.com (N.K.); ana.stupin@mefos.hr (A.S.); anitaa3006@gmail.com (A.M.); kozina.natasa@gmail.com (N.K.); zmihaljevic@mefos.hr (Z.M.); martina.mihalj@gmail.com (M.M.); psusnjara1@gmail.com (P.Š.); marko.stupin@gmail.com (M.S.); aleksandar_mf@yahoo.com (A.K.)

2 Scientific Center of Excellence for Personalized Health Care, Josip Juraj Strossmayer University of Osijek, Trg Svetog Trojstva 3, HR-31000 Osijek, Croatia; zeljka.breskic@gmail.com (Ž.B.Ć.); selthofer.relatic@gmail.com (K.S.-R.); lukinac28@gmail.com (A.L.); lukakolar.vu@gmail.com (L.K.); gkralik@fazos.hr (G.K.); zlata.kralik@fazos.hr (Z.K.); szealex@kemija.unios.hr (A.S.); mjozanovic@kemija.unios.hr (M.J.); ogalovic@kemija.unios.hr (O.G.); mmkosano@kemija.unios.hr (M.M.-K.)

3 Department of Pathophysiology, Physiology and Immunology, Faculty of Dental Medicine and Health, Josip Juraj Strossmayer University of Osijek, Cara Hadrijana 10E, HR-31000 Osijek, Croatia

4 Department of Dermatology and Venereology, University Hospital Osijek, HR-31000 Osijek, Croatia

5 Department for Cardiovascular Disease, University Hospital Osijek, J. Huttlera 4, HR-31000 Osijek, Croatia

6 Department of Internal Medicine, General Hospital Vinkovci, Zvonarska 57, HR-32100 Vinkovci, Croatia

7 Department for Internal Medicine, Faculty of Medicine, Josip Juraj Strossmayer University of Osijek, J. Huttlera 4, HR-31000 Osijek, Croatia

8 Department of Rheumatology, Clinical Immunology and Allergology, Clinical Hospital Center Osijek, J. Huttlera 4, HR-31000 Osijek, Croatia

9 Department of Internal Medicine, Vukovar General Hospital, HR-32000 Vukovar, Croatia

10 Nutricin j.d.o.o. Darda, HR-31326 Darda, Croatia

11 Department of Animal Production and Biotechnology, Faculty of Agrobiotechnical Sciences, Josip Juraj Strossmayer University of Osijek, Vladimira Preloga 1, HR-31000 Osijek, Croatia

12 Department of Chemistry, Josip Juraj Strossmayer University of Osijek, Cara Hadrijana 8/A, HR-31000 Osijek, Croatia

* Correspondence: ines.drenjancevic@mefos.hr

Abstract: Carnosine is a dipeptide synthesized in the body from $\beta$-alanine and L-histidine. It is found in high concentrations in the brain, muscle, and gastrointestinal tissues of humans and is present in all vertebrates. Carnosine has a number of beneficial antioxidant properties. For example, carnosine scavenges reactive oxygen species (ROS) as well as alpha-beta unsaturated aldehydes created by peroxidation of fatty acid cell membranes during oxidative stress. Carnosine can oppose glycation, and it can chelate divalent metal ions. Carnosine alleviates diabetic nephropathy by protecting podocyte and mesangial cells, and can slow down aging. Its component, the amino acid beta-alanine, is particularly interesting as a dietary supplement for athletes because it increases muscle carnosine, and improves effectiveness of exercise and stimulation and contraction in muscles. Carnosine is widely used among athletes in the form of supplements, but rarely in the population of cardiovascular or diabetic patients. Much less is known, if any, about its potential use in enriched food. In the present review, we aimed to provide recent knowledge on carnosine properties and distribution, its metabolism (synthesis and degradation), and analytical methods for carnosine determination, since one of the difficulties is the measurement of carnosine concentration in human samples. Furthermore, the potential mechanisms of carnosine's biological effects in musculature, metabolism and on immunomodulation are discussed. Finally, this review provides a section on carnosine supplementation in the form of functional food and potential health benefits and up to the present, neglected clinical use of carnosine. 
Keywords: oxidative stress; antioxidants; functional food; carnosine

\section{Introduction}

Carnosine is a dipeptide synthesized in the body from $\beta$-alanine and L-histidine. It was originally discovered in skeletal muscle [1] where it is present in larger amounts than in other tissues, but it is also found in high concentrations in the brain, heart, and gastrointestinal tissues of humans. It is an integral part of different tissues in all vertebrates, while plants do not contain it at all [2,3].

Although its physiological role has not been completely understood yet, carnosine is a non-enzymatic free-radical scavenger and a natural antioxidant [4] and has antiinflammatory and neuroprotective properties $[5,6]$. Furthermore, its numerous beneficial effects have now been well established including pH-buffering activity [7], heavy metal chelating activity [8], and antiglycating activity $[9,10]$. Carnosine reduces lipid peroxidation, but also inhibits oxidative modification of protein exposed to hydroxyl radicals [11]. Furthermore, it improves antioxidant capacity [12].

Studies have shown that the chronic oral ingestion of $\beta$-alanine can substantially elevate (up to $80 \%$ ) the carnosine content of human skeletal muscle, which is the major production and storage site for carnosine in the human body [13]. Furthermore, data indicate that carnosine has excellent potential for use as a natural antioxidant in processed foods [14], since it has been suggested to be absorbed intact through the intestine into the blood [15]. Under normal resting conditions, carnosine is low in plasma due to the large amount of carnosinase [16]. After meat digestion, the quantity of dietary carnosine available for intestinal absorption depends on its original concentration in food and also on its bioaccessibility [17]. For example, after beef consumption, carnosine is detected in plasma within $15 \mathrm{~min}$, reaching a maximum after $3.5 \mathrm{~h}$, whereas $5.5 \mathrm{~h}$ after carnosine consumption, carnosine concentrations fall below detectable serum carnosine values [18]. Since carnosine has several beneficial properties, evidence of its bioavailability suggests that it could be suitable for use as a functional food ingredient. The main differences between the ingestion of carnosine from food matrix vs. supplements (e.g., capsule) would be in its bioaccessibility and bioavailability. Indeed, the release and absorption rate of carnosine from meat products would be proportional to its original concentration in the food product and would depend on the gastrointestinal environment, while the absorption rate of carnosine upon ingestion of capsule supplements would be equal to the dose indicated on the label [19].

It is demonstrated that carnosine can prolong cell life and preserve cellular homeostasis [3]. Considering all beneficial properties of carnosine and its clinical use [20], carnosine can be recommended as a natural cure that has no side effects but is highly efficient [21]. Furthermore, natural dipeptide antioxidants (such as carnosine) are receiving increasing attention because of their noticeable potential as biopreservatives in food recent technology [22].

The aim of the present review was to summarize the current knowledge of the carnosine's biological properties in health and disease. Special attention is paid to the antiinflammatory and antioxidant properties of carnosine, and its effect on muscle function as well as beneficial effects in various diseases. To obtain a comprehensive overview of the current data, the original research papers and clinical trials as well as systematic reviews available on the PubMed database were analyzed by using the following search terms: carnosine, functional food, muscle, health, disease, vascular, endothelium, inflammation, antioxidants, and oxidative stress. Only the English language literature that referred to both humans and experimental animals with no time restriction were reviewed. A total of 76 clinical trials were found using search terms carnosine and supplementation, most of them were related to carnosine muscle content and physical capacity/exercise in health. An additional 14 clinical trials and one systematic review with meta-analysis were identified 
in PubMed by search terms carnosine, aging, human. Limited number of clinical studies were related to diseases, mostly diabetes and/or obesity, as discussed further in the text.

\section{Carnosine Metabolism}

Metabolic pathways in synthesis of carnosine. Carnosine is synthesized by bonding of the amino acids $\beta$-alanine (regulatory function) and L-histidine (biological activity), a reaction catalyzed by carnosine synthase $[6,9,23]$. $\beta$-alanine becomes available by hepatic breakdown of thymidine, uracil, and dietary dipeptides obtained from meat consumption and is considered to be a non-proteinogenic rate-limiting precursor of carnosine. L-histidine, on the other hand, is an essential amino acid present in serum and serves as a proteinogenic precursor with bioactive properties (Figure 1) [13].

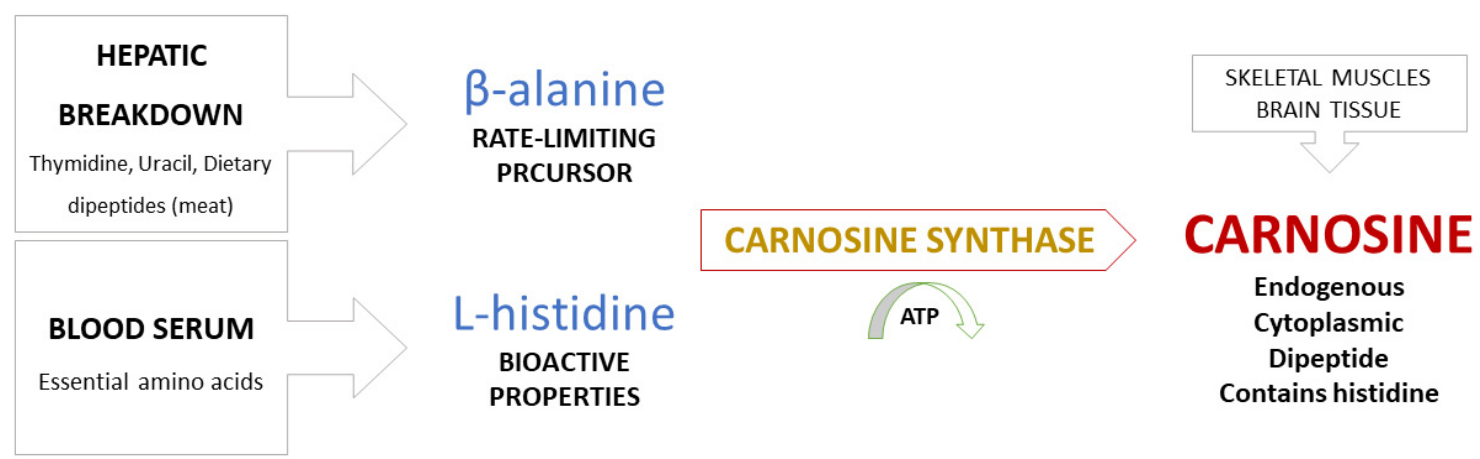

Figure 1. Synthesis of carnosine from precursor amino acids $\beta$-alanine and L-histidine.

Carnosine naturally occurs in numerous variants as carnosine derivatives including anserine and the ophidine/balenine-methylated imidazole ring of L-histidine; homocarnosine-GABA replaces $\beta$-alanine; carcinine-L-histidine is replaced by histamine; acetylcarnosine-acetylated $\beta$-alanine (Figure 2) [23]. Most common derivatives are mentioned methylated analogues, anserine, and ophidine, which are synthetized by carnosine $N$-methyltransferase mediated methylation of the imidazole ring. The same effect can also be achieved by enzymatic condensation of Npi-methylhistine with $\beta$-alanine through carnosine synthase, although the latter pathway is considered more physiologically relevant [3].

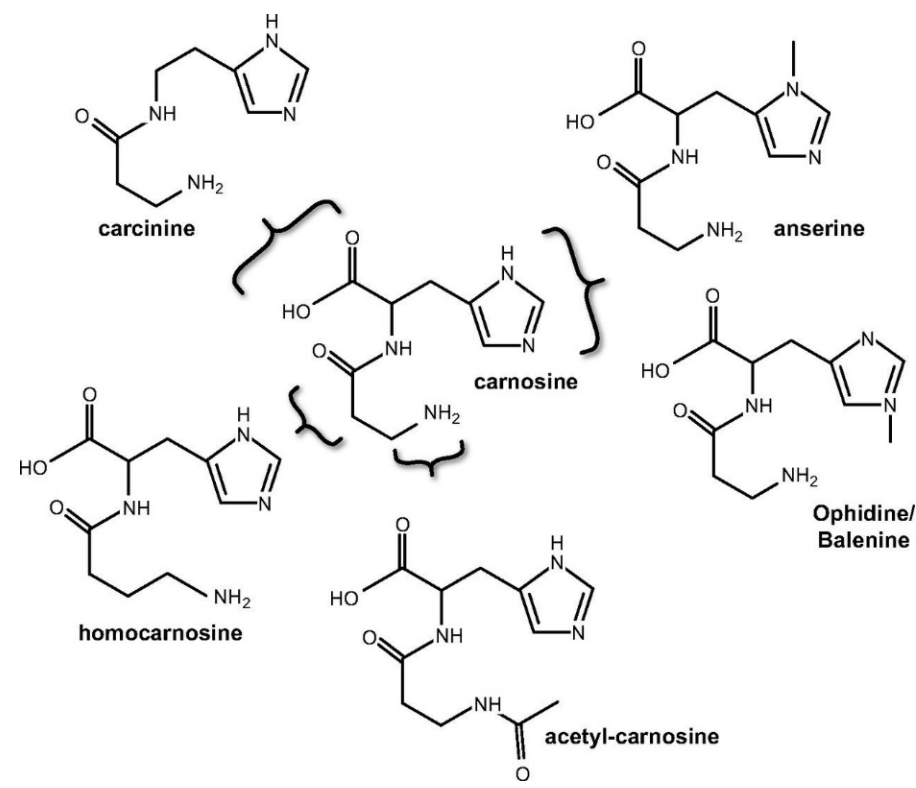

Figure 2. Chemical structures of carnosine and naturally occurring derivatives (figure adapted from Boldyrev et al. (2013) [3]). 
Metabolic pathways in breakdown of carnosine. Degradation of carnosine occurs in serum and tissues through hydrolysis, catalyzed only by the enzyme carnosinase. Common peptidases have no effect on the breakdown of the carnosine molecule, while non-enzymatic degradation of carnosine is non-existent $[3,6]$. These specificities indicate an extremely well regulated metabolism, especially the degradation process (Figure 3) [13].

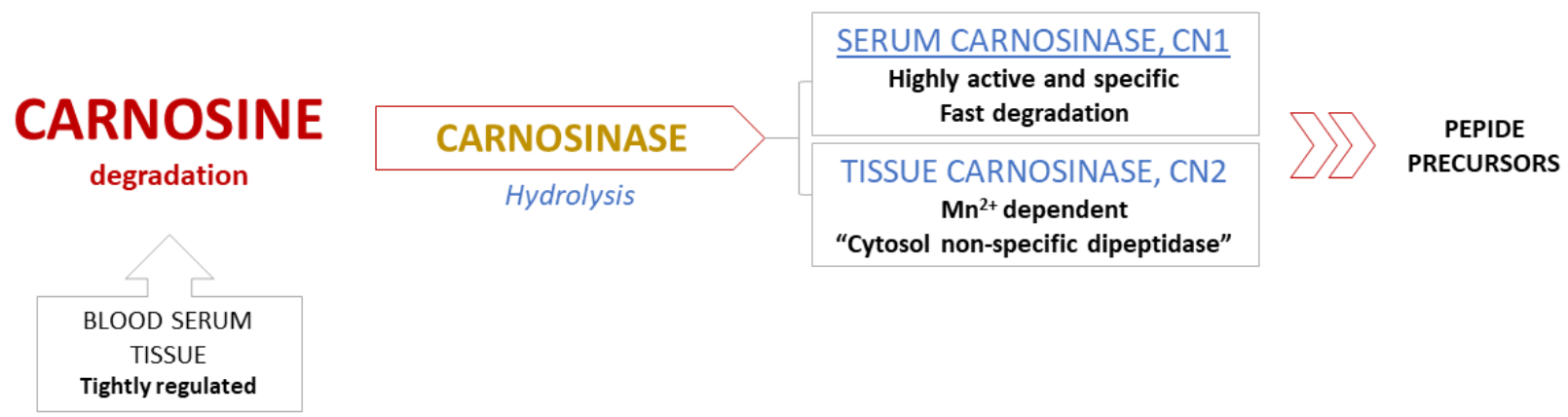

Figure 3. Degradation of carnosine.

There are two human isoforms of enzyme carnosinase: serum carnosinase (CN1) and tissue carnosinase (CN2). Highly active and abundant $\mathrm{CN} 1$, which is found in serum and brain tissue, catalyzes degradation of both carnosine and homocarnosine, while $\mathrm{Mn}^{2+}$ dependent $\mathrm{CN} 2$ is expressed only in tissues and described as "cytosol nonspecific dipeptidase" [24]. High activity and selectivity of serum CN1 results in fast degradation of circulating carnosine in human blood within $2-3 \mathrm{~h}$ following a meal, which is the reason behind the inability to detect this dipeptide after the fasting period $[13,25]$. This feature certainly presents a challenge and substantially limits the possibility of future therapeutic applications of carnosine [26].

Furthermore, a recent study suggests that human kidneys possess their own internal system for carnosine metabolism since it was found that enzymes and histidine-containing dipeptides were detected in specific nephron compartments [27]. Since there was no correlation between carnosine concentrations and $\mathrm{CN} 1$ activity in kidneys as previously suspected, local tissue related impact probably has a crucial role in carnosine metabolism, specifically in diabetic nephropathy development [28].

\section{Methodology of Carnosine Determination}

One of the significant problems in clinical human studies is sampling and the method of determination of the compound of interest.

Carnosine sampling and sample preparation. The sampling can be divided in two main groups: tissue and liquid biopsy. The collected sample are commonly frozen in liquid nitrogen and stored at $-85^{\circ} \mathrm{C}$ until further preparation for analyses [29-31].

Preparation of samples obtained by tissue biopsy. The content of carnosine is mainly determined in the vastus lateralis muscle [32]. Harris et al. [32] acquired a biopsy sample from the vastus lateralis muscle of male subjects aged 20-35. Biopsy samples were taken by using the Bergström technique (Bergström muscle biopsy cannula). After gathering, the samples were stored in liquid nitrogen and freeze-dried. Single muscle fiber was weighed, extracted, and analyzed with HPLC, as described by Dunnett and Harris [33]. The extraction of carnosine from tissue samples is described in many papers and differs in a solvent and buffer. We are presenting a summary of different extraction methods in Table 1. 
Table 1. Extraction of carnosine from human samples.

\begin{tabular}{cccccc}
\hline Sample & Deproteinization & Extraction Method & Separation Media & pH & Ref. \\
\hline muscle & perchloric acid & SPE & borate buffer & 9.6 & {$[32,33]$} \\
\hline muscle & n.a. & Liquid. & borate buffer & 9.6 & {$[34]$} \\
\hline muscle & n.a. & Liquid & water & n.a. & {$[35]$} \\
\hline muscle & $70 \%$ ethanol & Liquid. & water $/ \mathrm{NaOH}, \mathrm{HCl}$ & n.a. & {$[36]$} \\
\hline muscle & $35 \%$ sulfosalicylic acid & Liquid. & borate buffer & n.a. & {$[37,38]$} \\
\hline muscle & acetonitrile & Liquid. & hydrochloric acid & n.a. & {$[39]$} \\
\hline human plasma & $35 \%$ sulfosalicylic acid & Liquid. & borate buffer & n.a. & {$[28,37]$} \\
\hline human plasma & $35 \%$ sulfosalicylic acid & Liquid. & PBS buffer & n.a. & {$[18]$} \\
\hline human plasma & methanol & Liquid & water/formic acid & n.a. & {$[40]$} \\
\hline human plasma/urine & EDTA & Liquid & sodium acetate buffer & 6.4 & {$[41]$} \\
\hline
\end{tabular}

Preparation of samples obtained by liquid biopsy. Blood samples are usually collected for carnosine determination, but for certain experiments, carnosine is determined from cerebrospinal fluid (CSF) or urine [42]. Blancquaert et al. [37] collected samples of venous blood in EDTA-containing tubes, and samples were centrifuged. Deproteination of plasma was carried out using sulfosalicylic acid (35\%), samples were centrifuged and the supernatant was used for further preparation and analysis [29,38,42]. Park et al. [18] determined carnosine concentration in human plasma after the dietary consumption of beef. Within one hour of sample collection, samples were centrifuged at $4{ }^{\circ} \mathrm{C}$, and $5 \mathrm{~mL}$ of plasma was vortex-mixed with the addition of perchloric acid and heated in a boiling water bath. Samples were again centrifuged, and the supernatant was filtered and used for analysis.

Pandaya et al. [40] collected blood samples (in EDTA-containing tubes), plasma was separated and stored at $-80^{\circ} \mathrm{C}$ until further preparation for HPLC analysis. For analysis, $100 \mu \mathrm{L}$ of plasma was taken. Proteins were precipitated by adding chilled methanol in a 1:4 ratio and separated by centrifuge. The collected supernatant was passed through the Costar spin column. The flow-through was speed-vac dried and reconstituted in $50 \mu \mathrm{L}$ of water containing 3\% ACN. LC-MS/MS was used for sample analysis.

\section{Analytical Methods for Carnosine Determination}

Nuclear magnetic resonance (NMR) spectroscopy is a rapid method to provide complete structural analysis, with or without sample pre-treatment in both liquid and solid samples [43]. However, it is less sensitive than mass spectrometry.

Carnosine can be determined in tissues by non-invasive magnetic resonance imaging (MRI) and proton magnetic resonance spectroscopy (1H-MRS). In muscle, signal output predominantly originates from carnosine. However, in the brain, homocarnosine is predominant [44]. Özdemir et al. determined carnosine concentration in human muscle in vivo by proton magnetic resonance spectroscopy [45].

HPLC is the most commonly used method for determining carnosine, and it has an appropriate separation and selectivity accompanied with sufficient sensitivity provided by the large variety of detection methods. However, analysis of carnosine in complex samples by liquid chromatography can suffer stationary phase damage from matrix species and often requires the use of precolumn, large quantities of organic solvents, and bulky instrumentation [46]. A summary of different sample preparations and detections is presented in Table 2. 
Table 2. HPLC analysis.

\begin{tabular}{|c|c|c|c|c|c|c|}
\hline Protocol & Column & Detection & $\begin{array}{c}\text { Derivatization } \\
\text { Reagent }\end{array}$ & $\begin{array}{l}\text { Sample } \\
\text { Matrix }\end{array}$ & $\begin{array}{l}\text { Limits of } \\
\text { Detection }\end{array}$ & Ref. \\
\hline RP-HPLC & Hypersil ODS & Fluorescent & $\begin{array}{l}\text { 3-mercaptopropionic } \\
\text { acid/o-phthaldehyde }\end{array}$ & muscle & $0.005 \mathrm{mmol} / \mathrm{kg}$ & {$[32,33]$} \\
\hline RP-HPLC & APEX ODS & Fluorescent & $\begin{array}{l}\text { 3-mercaptopropionic } \\
\text { acid/o-phthaldehyde }\end{array}$ & muscle & $0.005 \mathrm{mmol} / \mathrm{kg}$ & [34] \\
\hline RP HPLC & Hypersil ODS & Fluorescent & $\begin{array}{l}\text { 3-mercaptopropionic } \\
\text { acid/o-phthaldehyde }\end{array}$ & muscle & $0.005 \mathrm{mmol} / \mathrm{kg}$ & [35] \\
\hline JLC-300 & LCR-6 & n.a & n.a. & muscle & $0.005 \mathrm{mmol} / \mathrm{kg}$ & {$[36]$} \\
\hline RP HPLC & XBridge BEH & Fluorescent & AccQTag & muscle & n.a. & {$[38]$} \\
\hline RP HPLC & Hypersilica & UV (210 nm) & n.a. & muscle & 3 and $10 \mu \mathrm{M}$ & {$[41]$} \\
\hline RP HPLC & HILIC silica & UV (214 nm) & n.a & muscle & & [39] \\
\hline RP HPLC & Hypersil ODS & Fluorescent & $\begin{array}{l}\text { 3-mercaptopropionic } \\
\text { acid/o-phthaldehyde }\end{array}$ & $\begin{array}{l}\text { human } \\
\text { plasma }\end{array}$ & & [18] \\
\hline UPLC & $\begin{array}{c}\text { Acquity } \\
\text { Peptide BEH } \\
\text { C18 }\end{array}$ & MS & n.a. & $\begin{array}{l}\text { human } \\
\text { plasma }\end{array}$ & & [40] \\
\hline RP HPLC & Jupiter C18 & Fluorescent & $\begin{array}{l}\text { carbazole-9-carbonyl } \\
\text { chloride (CFC) }\end{array}$ & $\begin{array}{l}\text { human serum, } \\
\text { animal feed }\end{array}$ & $15 \mathrm{nM}$ & [28] \\
\hline
\end{tabular}

Capillary electrophoresis and Microchip electrophoresis. Nowadays, capillary electrophoresis (CE) and capillary electrochromatography (CEC) are recognized analogs of HPLC/ UHPLC and nano-LC methods [47].

Carnosine can be determined in biological materials by capillary electrophoresis with UV detection [48], laser-induced fluorescence (LIF) mass spectrometry [49], and microchip electrophoresis (ME) with chemiluminescence [50] or capacitively coupled contactless conductivity detection (C4D) [51]. An important constraint of capillary electrophoresis is the limited sensitivity due to the small volume of the injected sample. Two different approaches can be employed for improving sensitivity: applying sensitive detectors such as laser-induced fluorescence and mass spectrometry or using preconcentration techniques such as sample stacking methods or isotachophoresis (ITP) [47]. Several techniques have been developed with improved sensitivity $[48,50,52]$.

Microchip electrophoresis (ME) is a miniaturized mode of CE [53]. ME was first used to analyze carnosine by Zhao et al. in 2009 [50]. Chemiluminescent detection was used to determine the carnosine, anserine, and homocarnosine in biological materials [54]. For the carnosine to become detectable by the chemiluminescent detector, it needs to be labeled; for this purpose, $\mathrm{N}$-(4-aminobutyl)- $N$-ethylsoluminol (ABEI) was used as a precolumn marker [54].

$M A L D I-T O F-M S$ is a new and powerful technique for examining biological samples and plays a significant role in modern life sciences [55]. Pisarev et al. [56] reported an ultra-sensitive method for the determination of carnosine. The limit of detection is in the picomolar range. Moreover, the concentration can be determined directly on site of a tissue sample without carnosine extraction. Even more sensitive methods have been developed by combining separation with electrospraying and detection by MS [57].

Electrochemical methods are rarely used for carnosine determination, but it is worth mentioning that they are widely used to characterize amino acids and peptides. Jozanović et al. [58] studied carnosine and anserine at the glassy carbon electrode with differential pulse voltammetry. They found that both dipeptides were oxidized, and their oxidation mechanism involves the transfer of one electron and one proton. The optimal 
$\mathrm{pH}$ for the oxidation of carnosine was 4.8 and for the oxidation of anserine it was 6.1, respectively. A linear relationship between the peak current and the carnosine and anserine concentration in the range of $1 \times 10^{-5} \mathrm{M}$ to $1 \times 10^{-4} \mathrm{M}$ was established.

\section{Challenges in Carnosine Examination}

Carnosine is a nutrient highly abundant in beef. Daily dietary intake of $30 \mathrm{~g}$ dried beef can completely supply daily carnosine requirement of the 70-kg adult to ameliorate human nutrition and health [59]. However, reported amounts of carnosine in beef meat are very inconsistent in the literature and may vary greatly [60] from $14 \mathrm{mg}$ [61] to $1 \mathrm{~g}$ [62] of carnosine in $100 \mathrm{~g}$ wet beef meat. It is assumed that such large differences in nutrient composition may result, in part, from analytical methods or beef breeds [59]. Interestingly, it is suggested that some components in beef inhibit serum carnosinase [3], causing an elevated circulating amount of carnosine that may directly endue the dipeptide to extraintestinal tissues and cells. On the other hand, it is difficult to estimate the extent to which substances from food (anserine, amino acids (e.g., histidine and $\beta$-alanine), and copper) affect carnosinase activity. Furthermore, a particular challenge is to determine the basal amount of carnosine in the human body, since carnosine is negligible or not detectable in the human plasma, and muscle biopsy is an invasive procedure.

The next important challenge lies in the fact that $\beta$-alanine availability primarily limits carnosine synthesis in human skeletal muscle, but a diet sufficient supply of histidine is also important for carnosine synthesis [34,63]. Studies reported that in humans consuming enough histidine from animal-source foods that histidine is not a limiting factor in the synthesis of carnosine, and in nonvegetarian adults, an equal intake of $\beta$-alanine and carnosine successfully enhances muscular carnosine amount to the identic extent. However, in vegetarians, it is unrevealed whether histidine dietary intake limits carnosine synthesis with or without $\beta$-alanine supplementation [64].

\section{Carnosine Biological Effects}

\subsection{Carnosine in Muscle Function}

Although it is well known that carnosine plays an important role in exercise performance and skeletal muscle homeostasis [65], its definitive role is still not established [3]. Carnosine functions as a high-energy phosphate system comparable to the creatine/ phosphocreatine system [66]. In their experiments, Severin et al. [67] demonstrated that carnosine plays a role in contractile function of skeletal muscle. In nerve-muscle preparation of frogs, it has been shown that the offset of the fatigue could occur during rhythmic nerve-stimulated muscle contractions if $10 \mathrm{mM}$ of carnosine was added to the surrounding medium. This is also true for anserine [68]. Below, we summarize the currently best-established physiological roles of carnosine in skeletal muscle.

Intramyocellular $\mathrm{pH}$ buffering. The role of carnosine as a $\mathrm{pH}$ buffer was first proposed in the early works of Bate Smith [69] and Deutcsh and Eggleton [70]. Although the specific mechanism is still unknown, it has been established that increasing carnosine via $\beta$-alanine supplementation improves exercise capacity and performance in exercise in durations of $30 \mathrm{~s}$ to $10 \mathrm{~min}$ [71]. This result is consistent with carnosine acting as a $\mathrm{pH}$ buffer because $\mathrm{H}^{+}$concentrations in muscle are highest after exercise. The greatest benefit for exercise capacity is shown from increasing carnosine content [72]. Carnosine is a mobile buffer that can dissolve in cytoplasm, whereas proteins are fixed buffers [73]. Carnosine contribution to $\mathrm{pH}$ homeostasis is allowed by such mobility [74]. When the amount of carnosine in skeletal muscle is increased by nutritional intervention, the level of blood acidosis during high-intensity exercise is reduced in humans [75].

In addition to its buffering effects in muscle, carnosine protects against reactive oxygen species (ROS) produced during an exercise as reported in Dawson et al. [76]. Their study on downhill running in rats showed that a supplementation-induced increase in muscle histidine-containing dipeptides could diminish the production of thiobarbituric acid reactive substances (TBARS, lipid peroxidation products). This observation is consistent 
with earlier studies reporting a protecting function of carnosine on lipid peroxidation in working muscles [77].

Effect on $\mathrm{Ca}^{2+}$ handling and muscle contractility. Regulation of the excitation-contraction coupling in skeletal muscle is a complex sequence of events in which calcium is released from the sarcoplasmic reticulum (SR) through ryanodine receptors (RyR). Calcium binding to troponin C allows cross-bridge formation and production of force, and after that, the reuptake of calcium in the SR terminates contraction [78]. Carnosine may be included in the regulation of several of these steps. Release of $\mathrm{Ca}^{2+}$ induced by carnosine in SR vesicles from rabbit white skeletal muscles was demonstrated by Batrukova and Rubtsov [79] with constituent amino acids L-histidine and $\beta$-alanine. Similar evidence was presented in a study on chemically skinned fibers of human vastus lateralis muscle [80]. Considering that $\mathrm{Mg}^{2+}$ has a strong inhibitory effect on RyR [81], these findings were challenged [82], arguing that $\mathrm{Mg}^{2+}$ levels were abnormally low in previous studies and they demonstrated that in physiological levels of $\mathrm{Mg}^{2+}$, carnosine does not play a role in stimulating the RyRs. Calcium sensitivity of contractile apparatus is probably even more important for carnosine's effect on excitation-contraction coupling. These were demonstrated in studies on animals, but also in studies on skinned human muscle fibers $[83,84]$.

Cytoplasmic $\mathrm{Ca}^{2+}-\mathrm{H}^{+}$exchanger. Carnosine may function as a diffusible cytoplasmic $\mathrm{Ca}^{2+}-\mathrm{H}$ exchanger in cardiomyocytes [74]. Elements of two previously discussed roles are combined in this function: $\mathrm{Ca}^{2+}$ and $\mathrm{pH}$ buffering. The interrelationship between $\mathrm{H}^{+}$and $\mathrm{Ca}^{2+}$ has an important role in exercising skeletal muscle because $\mathrm{H}^{+}$can compete with $\mathrm{Ca}^{2+}$ at the troponin-binding site and by that, limit the ability of the muscle contractile machinery to operate effectively [85]. Ability of $\mathrm{Ca}^{2+}$ and $\mathrm{H}^{+}$to competitively bind to carnosine can cause unloading of $\mathrm{Ca}^{2+}$ in areas of high $\mathrm{H}^{+}$production and the other way around [74]. A role of carnosine as the $\mathrm{Ca}^{2+}-\mathrm{H}^{+}$exchanger in human skeletal muscle could be explained by the fact that an increase in carnosine level can reduce half-relaxation time [86]. The main role in relaxation time has the rate of dissociation of $\mathrm{Ca}^{2+}$ from troponin, translocation of $\mathrm{Ca}^{2+}$ to a site close to the SR, and reuptake of $\mathrm{Ca}^{2+}$ into the SR by SERCA pumps (SR $\mathrm{Ca}^{2+}$-ATPase) [82]. Carnosine, as a mobile buffer, may translocate $\mathrm{Ca}^{2+}$ closer to the SERCA pump for $\mathrm{Ca}^{2+}$ reuptake. This was demonstrated in rat ventricular cardiomyocytes [74], where spatiotemporal responses in $\mathrm{Ca}^{2+}$ stimuli are different from skeletal muscle $[68,87]$. It is possible that this also occurs in human skeletal muscle, but validation is required before making strong conclusions.

Muscle as storage and release organ for carnosine. Muscle contains most of the carnosine present in the organism, and it is tempting to speculate on the possible role of skeletal muscle as a depot and donor of carnosine. Carnosine level in human skeletal muscle (without carnosine or $\beta$-alanine supplementation) is in the range from 5 to $10 \mathrm{mM}$ [3], or $16.7-33.3 \mathrm{mmol} / \mathrm{kg}$ dry weight of muscle. Carnosine amount depends on muscular activity and bodybuilders may have average values from $13 \mathrm{mmol}$ or $43 \mathrm{mmol} / \mathrm{kg}$ dry weight [88]. One of the early discoveries were that tissues that are capable of synthesizing carnosine should not be able to provide for its degradation [68]. Carnosine could play an autocrine, paracrine, or even endocrine role, especially during exercise. This was supported by the findings of Nagai et al. [89] who detected a doubled carnosine concentration in plasma of rats who were trained on a running wheel compared with sedentary rats. It was also shown that in human skeletal muscle during knee extension exercise at $20 \mathrm{~W}$, carnosine content markedly increases in the interstitial fluid, determined by microdialysis [90]. It is still unknown whether carnosine exempt from muscle cells is an outcome of a functional transporter acting or a result of sarcolemmal rupture [3]. This contraction-included release system is yet inaccessible, but may be linked to the interaction between carnosine, histidine, and histamine [91].

Direct effects on aerobic metabolism and glycolysis. Early research showed that in isolated skeletal muscle, carnosine regulates enzyme activity and chelates heavy metal glycolytic inhibitors, which leads to an increase in glycolytic flux [92,93]. Despite success in vitro, data of direct influence on energy metabolism in human skeletal muscle are equivocal. 
Independently of oxidative capacity, increase in glycolytic flux or capacity is quantifiable by higher lactate accumulation during and after exercise. Some of the studies with $\beta$-alanine supplementation has shown this with an increase in post exercise plasma lactate values. Some studies measured blood lactate after a special judo fitness test [94] and $4 \times 30$ s upperbody Wingate test [95]. However, in these studies, direct effects on glycolysis could not be separated from indirect effects because the total mechanical work was not matched between pre-supplementation and post-supplementation trials. Only a few studies have quantified the effects of $\beta$-alanine supplementation on energy system contribution with matched total mechanical work and reported that after a high-intensity intermittent cycling test, a decrease in post exercise muscle lactate and oxygen deficit was detected [96]. Additionally, a small $(1.3 \%)$ but significant increase in the estimated aerobic energy contribution was observed. Another study using treadmill running showed that $\beta$-alanine supplementation induced delay in the onset of blood lactate accumulation and indicated an improvement in oxidative capacity [97]. Despite good results in vitro, the influence of carnosine as a direct modulator of energy metabolism in skeletal muscle appears to be less noticeable.

Carnosine content in skeletal muscle depends on a variety of individual factors including age, gender, diet, distribution, muscle fiber distribution, and training status. The carnosine content in type II fibers is approximately 30-100\% higher than the carnosine content in type I fibers, further demonstrating the importance of carnosine during high-intensity activity $[34,35,98]$.

$\beta$-alanine or carnosine dietary supplementation improves muscular performance in humans [65]. It is reported that $\beta$-alanine dietary supplementation ( $6 \mathrm{~g} /$ day for 23 days) decreases the histidine plasma and muscle concentrations [37], whereas oral administration of carnosine enhances the $\beta$-alanine but also histidine levels in the human plasma [99], suggesting the advantage of the carnosine supplementation (synthetic or carnosine-rich foods) over the consumption of $\beta$-alanine alone.

Definitive role of carnosine in skeletal muscle is still unknown, but earlier described functions are possibly the most important roles of carnosine in skeletal muscle. Other potential roles of carnosine are under investigation such as activation of myosin ATPase, effects on glycolysis, neuromuscular junction, and mitochondrial respiration [3]. Those potential roles of carnosine are up to this day still poorly understood.

\subsection{Antioxidant and Anti-Inflammatory Properties of Carnosine}

The antioxidant activity of carnosine is mediated by different mechanisms involving metal ion chelation, and scavenging of ROS and peroxyl radicals [3]. The most important antioxidant effects of carnosine are summarized in Figure 4.

A study that examined the effect of carnosine on oxidative stress in human kidney tubular epithelial (HK2) cells indicated that carnosine decreased NADPH oxidase (Nox) 4 expression and increased total superoxide dismutase (T-SOD) activity, thus reducing the production of intracellular ROS, relieving the oxidative stress of cells, and ultimately inhibiting the mitochondrial pathway of apoptosis [100].

Ability of carnosine to protect against pathologies characterized by oxidative stress has been shown in a number of conditions. Products of such modification usually lose ability to carry out their functions [101]. Carnosine changes the reactivity of superoxide anion by forming a charge-transfer complex with the superoxide radical [102] and also by reducing the efficiency of hydroxyl radicals, creating a compound less reactive than the hydroxyl radical [103]. One of the mechanisms to protect organisms from oxidative stress is the chelation of transition metals, preventing them from participating in deleterious processes involving $\operatorname{ROS}[104,105]$. In the case of the $\mathrm{Cu}^{2+}$-carnosine complex, $\mathrm{Cu}^{2+}$ is bound to some organic compounds like imidazole, forming two six-membered chelate rings [106]. In the presence of copper, the fast oxidation of carnosine by $\cdot \mathrm{OH}$ still takes place and yields adducts of $\cdot \mathrm{OH}$ radicals at the imidazole ring. Imidazole compounds are known to react with singlet oxygen forming endoperoxide products and that group is the preferred site for $\cdot \mathrm{OH}$ binding in the presence of copper [107]. Regarding this, carnosine showed an 
efficient chelator of copper and other transition metals and reacted with singlet oxygen several times faster than other tested parameters (like L-histidine) [108]. Interestingly, when comparing metals involved in free radical generation, carnosine was found to have a greater antioxidant activity coupled with copper than iron [109]. Furthermore, Decker et al. showed that purified carnosine scavenges peroxyl radicals and that scavenging is largely due to the L-histidine residue. Carnosine does not act as an electrotransfer agent because they were not able to reduce $\mathrm{MbFe}(\mathrm{III})$ to $\mathrm{MbFe}(\mathrm{II}) \mathrm{O}_{2}$, as shown in the model of Zucker obese rats [110].

Oxidative stress $\rightarrow$ production of large amounts of ROS

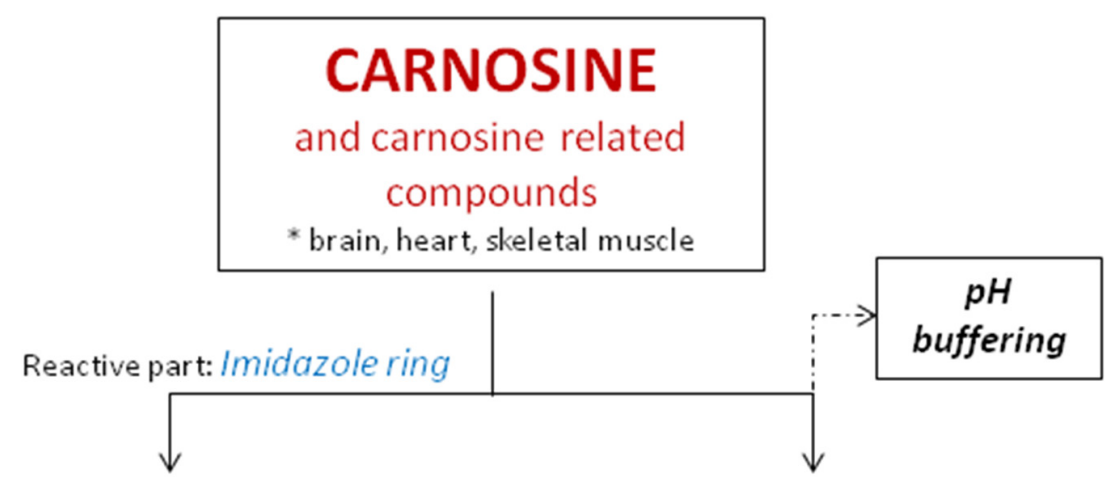

\section{(1) ROS SCAVENGER}

$\mathrm{H}_{2} \mathrm{O}_{2}, \mathrm{HO}, \mathrm{O}_{2} \cdot{ }^{-1}{ }^{1} \mathrm{O}_{2}$

$\alpha, \beta$-aldehyde
(2) METAL ION CHELATION

$\checkmark \mathrm{Cu}^{2+}, \mathrm{Co}^{2+}, \mathrm{Ni}^{2+}, \mathrm{Cd}^{2+}, \mathrm{Zn}^{2+}$

\section{CARNOSINE + \\ (1) SUPEROXIDE ANIONS HIDROXY RADICALS \\ (2) \\ TRANSITION METALS $\mathrm{Cu}^{2+}, \mathrm{Co}^{2+}, \mathrm{Zn}^{2+}, \mathrm{Ni}^{2+}, \mathrm{Cd}^{2+}$

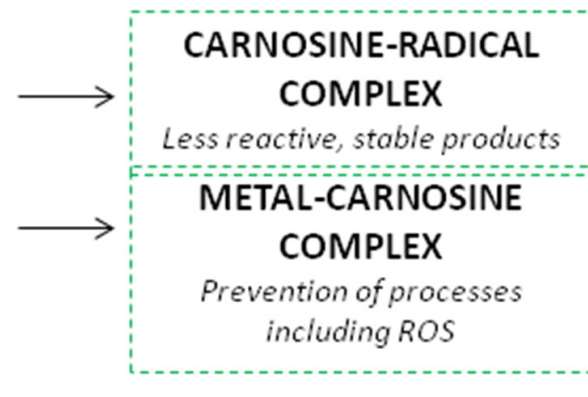

个 SOD, CAT, GPX activity

$\downarrow$ TBARS (MDA)

$\downarrow$ CELL APOPTOSIS

$\downarrow$ LIPID PEROXIDE PRODUCTION

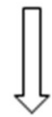

Inhibition of LIPID OXIDATION and neutralization of oxidized products

Figure 4. Schematic overview of the antioxidant effects of carnosine. 
At physiological concentrations, carnosine directly reacts with superoxide anion similar to ascorbic acid [111]. In physiological conditions, carnosine was found to reduce oxidative damage and to improve antioxidant activity of different antioxidative enzymes (such as SOD, GPx ... ) [11]. Experiments on aged rats showed that therapy with $250 \mathrm{mg} / \mathrm{kg} /$ carnosine per day significantly decreased oxidative stress and increased activity of antioxidative enzymes [112]. The same effect was not found in young rats. In similar model of aged rats, carnosine increased liver vitamin E, which further demonstrates its importance in defending the organism from free radicals [112].

Rising data indicate that carnosine acts as a scavenger of reactive and cytotoxic carbonyl species including 4-hydroxynonenal (HNE) [113]. HNE is an aldehyde generated endogenously by lipid peroxidation of unsaturated fatty acids [114] that act as 'toxic second messengers', extending the harmful potential of free radicals [115]. HNE is considered an important biomarker of oxidative stress and accumulating data indicate that it may modulate signaling pathways of cell proliferation, apoptosis, and inflammation [116]. At low and physiological levels, HNE acts as an endogenous signaling molecule, but at high concentrations, HNE is involved in the onset of several chronic diseases [117]. Because biological activity of HNE is related to its intracellular levels, the processes of maintaining its intracellular concentrations are most important, both in the defense against oxidative stress but also in the pathophysiology of several disease processes [117]. Carnosine can form conjugates with HNE and, therefore could prevent the toxicity of HNE and associated aldehydes [118]. Carnosine adduction to HNE appears to start with the generation of a reversible $\alpha, \beta$-unsaturated imine, followed by ring closure through an intra-molecular Michael addition [113]. In therapeutic observation, it was demonstrated that dietary carnosine supplementation prevents atherogenesis by facilitating aldehyde removal from atherosclerotic lesions in apolipoprotein E-null mice [119]. Taken together, carnosine endogenous concentration may be significant determinants in the formation of atherosclerotic lesion, and carnosine treatment could be a valuable approach for the prevention or treatment of atherosclerosis [119].

Furthermore, the accumulation of HNE has been extensively documented in blood and tissue samples from obese/diabetic patients [120,121], and emerging studies have indicated that these reactive aldehydes are more than simply markers of oxidative stress. Rather, it is suggested that these reactive species may play a significant pathogenic role in obesity-associated disorders such as insulin resistance [122,123], and a carnosine analog alleviates the production or enhances the removal of reactive carbonyl species, providing promising new therapeutic compounds for cardiovascular and metabolic diseases related to obesity [123].

Through its effect on the immune system, carnosine decreases both oxidative stress and inflammation, as demonstrated in the model of amyloid-induced inflammation [124]. The mechanism of this carnosine action is the interaction with specific receptors localized on the cell membrane, which modulate macrophage function by increasing their phagocytotic activity [125]. In addition, a study on the RAW 264.7 (murine macrophage cells) cell model showed that carnosine reduced phorbol 12-myristate 13-acetate (PMA) induced oxidative stress in macrophages by decreasing the expression of Nox1 and Nox2 genes as well as the intracellular superoxide anion levels [124].

\subsection{Immunomodulation}

Numerous studies provide evidence of the beneficial effect of carnosine supplementation on cytokine release, and consequently inflammation in humans and animals as follows [126-130]. For example, carnosine can lower renal interleukin-6 (IL-6) and tumor necrosis factor-alpha (TNF- $\alpha$ ) in rats after nickel-induced nephrotoxicity [131].

Elevated levels of pro-inflammatory cytokines such as IL- 6 and TNF- $\alpha$ are usually related to insulin resistance and alteration of insulin sensitivity in diabetic patients, while they can also be used as markers of renal damage in relation to diabetic nephropathy [131-134]. Hence, the in vivo effect of carnosine and histidine supplementation through drinking 
water was studied in diabetic Balb/cA mice [135], and these studies suggest that increased IL- 6 and TNF- $\alpha$ in diabetic mice were significantly suppressed by the intake of histidine or carnosine.

Several human pilot studies have investigated the effect of carnosine supplementation [59,136-138]. An increase in fasting insulin levels and insulin resistance was hampered in individuals receiving carnosine supplementation [136].

Additionally, it has been suggested that carnosine supplementation prevented worsening of insulin resistance in non-diabetic overweight and obese individuals [136], but also carnosine may have beneficial effects on the plasma lipidome [137]. Since excessive generation of IL- 6 and TNF- $\alpha$ compromise insulin sensitivity, suppression of IL- 6 and TNF- $\alpha$ by carnosine and histidine can have beneficial effects on reducing or preventing diabetesrelated complications as well as preventing altered endothelial function by inflammation.

Overexpression of pro-inflammatory IL-8, along ide IL- 6 and TNF- $\alpha$, has been associated with inflammatory processes in the digestive system, particularly in the intestines, inducing inflammatory bowel disease (IBD) [139]. Several studies have found that carnosine inhibits hydrogen peroxide and TNF- $\alpha$ stimulated secretion alongside mRNA expression of IL-8 in human intestinal epithelial cells [140,141]. In ulcerative colitis, as one of the inflammatory bowel diseases, research is being conducted to predict disease relapse. Reduced plasma histidine levels, which is an integral part of carnosine, predicts the risk of ulcerative collitis relapse [142].

In a similar manner, carnosine and histidine supplementation exhibited a hepatoprotective effect. Specifically, results of studies conducted on male Balb/cA mice with ethanolor acetaminophen-induced chronic liver injury indicated that both pre-(acetaminophen) and post-intake (ethanol) of carnosine and histidine decreased hepatic levels of IL-6 and TNF- $\alpha[143,144]$.

Potential beneficial impacts of carnosine and derivative anserine on inflammatory cytokine secretion was observed in neurodegenerative disorders, specifically Alzheimer's disease (AD) and Parkinson's disease (PD) [127,145]. The mentioned animal study was carried out on C57BL/ 6 mice with PD induced by administration of 1-methyl-4-phenyl1,2,3,6-tetrahydropyridine (MPTP), while a human study examined the effect on preserving cognitive function in elderly volunteers. It was found that anserine and/or carnosine supplementation significantly decreased IL-6, TNF- $\alpha$, and IL-1 $\beta$ in pre-treated mice with MPTP-induced PD, while in human subjects, there was a significant decrease of IL-8 and IL-5 detected in the treated group [72,146].

Animal studies have shown that carnosine has a beneficial effect on reducing acute kidney injury due to septic shock $[147,148]$. Carnosine renormalized lipid peroxidation, reduced the level of IL- $\beta$, tumor necrosis factor-alpha (TNF- $\alpha$ ), and macrophage inhibitory factor (MIF), thus demonstrating a beneficial effect in sepsis [149].

Although there are studies that suggest a potential beneficial role of carnosine in clinical conditions, there is insufficient data and there are still many unknowns. Additional experimental and clinical research in humans is needed in order to elucidate the mechanisms of carnosine application in these diseases as well as to more stringently test for clinical efficacy and potential adverse effects.

\subsection{Carnosine and Aging}

There are very few clinical trials concerned with the effects of $\beta$-alanine or carnosine supplementation on exercise capacity or the muscle carnosine content in elderly subjects. A PubMed database search with terms carnosine, aging, human, restricted to clinical trials, retrieved 14 publications. One trial was excluded due to the age of the participants (mean 25 years) and five others due to topic (skin health or vision) and another one was excluded due to the inability to obtain access to the full text and the paper was a combination of a review and pilot study. In the other analyzed clinical trials, the supplementation protocols differed, mainly including at least a month of beta-alanine or carnosine intake from $800 \mathrm{mg}$ to $2.5 \mathrm{~g} /$ day. It has been demonstrated that $\beta$-alanine supplementation increased exercise 
capacity and improved the ability of $\beta$-alanine to extend exercise duration [150]. Twentyeight days of $800 \mathrm{mg} /$ day of $\beta$-alanine supplementation increased cycling performance via an enhanced time to exhaustion and total work completed with associated lactate clearance during passive rest in female master athletes [151] and increased their peak torque and work completed, indicating $\beta$-alanine improves lower-body exercise performance [152]. Another study in eighteen healthy elderly subjects of both sexes showed that $\beta$-alanine intake was effective in increasing the muscle carnosine content, subsequently improving their exercise capacity [153]. Taken together, these results are promising, suggesting that supplementation of carnosine or its precursors could have a beneficial effect on muscle strength, endurance, and improved functionality in elderly people. However, due to a small number of involved subjects and diversity in their locomotor capacity at the enrollment, it is necessary to conduct research on a much bigger scale. In addition, there has been no study investigating the effects of consuming functional food enriched with carnosine or beta-alanine on physical performance in an elderly population.

Another important topic in aging is preservation of cognitive function and the potential of carnosine as an antioxidant to contribute to this goal. Sixty healthy elderly volunteers participated in a double-blind randomized controlled trial, receiving $1.0 \mathrm{~g}$ of anserine/carnosine (ASC) (3:1) for three months. There was a significant correlation between the preservation of verbal memory and suppression of CCL24 expression in persons taking ACS, suggesting that ACS intake preserves verbal episodic memory, probably due to inflammatory chemokine -CCL24 suppression in the blood [130], in agreement with a previous finding that ACS treatment decreases the production of CCL-2, IL-8 in elderly people and improves brain perfusion [145]. Nutraceutical supplements containing carnosine have been shown to improve some cognitive functional tests in the elderly [154], while recent systematic review and meta-analysis suggest that administration of carnosine/anserine for 12 weeks at a dose of $1 \mathrm{~g} /$ day may improve global cognitive function, but not depressive symptoms in elderly subjects [155].

\section{Carnosine Supplementation}

Chicken meat supplemented with carnosine. Supplementation with carnosine (and other histidine-containing dipeptides as well as their components) have been proposed as potential strategies for the prevention of chronic diseases [156]. Native chicken is an important possible source of functional food because it contains considerable amounts of bioactive compounds when compared with commercial broiler chicken and other meat [157]. Due to the above demonstrated beneficial effects of carnosine on metabolism in many organs and tissue, there has been an attempt to produce meat enriched with carnosine (so called functional food). For example, Kai et al. [158] investigated the influence of the three levels of histidine in broiler feed: $67 \%$ (low), $100 \%$ (control), and 200\% (high) compared to NRC recommendations (1994). They found out that carnosine and anserine levels in muscle control groups of chickens were $1434 \pm 86.3$ and $5902 \pm 153.5 \mu \mathrm{g} / \mathrm{g}$ of muscle, while high levels of histidine in feed increased the content of carnosine to $2464,8 \pm 185.6$, and anserine $6652.5 \pm 287.8 \mu \mathrm{g} / \mathrm{g}$ of muscle. However, Tomonaga et al. [159] found that histidine supplementation in chicken feed increased only carnosine content, but not anserine content. The muscles of the breast contain higher concentrations of carnosine compared to the muscles of the drumstick and thighs [160]. Some authors such as Kralik et al. [161] increased the $\beta$-alanine $(0.0 ; 0.5$ and $1.0 \%)$ and L-histidine $(0.0 ; 0.3$ and $0.5 \%)$ concentration in feed aiming to increase the content of carnosine (Table 3). They found a more efficient effect of higher amino acid concentrations on carnosine deposition in the chicken breast muscles. The carnosine concentration in the poultry body can be modified by adding amino acids ( $\beta$-alanine and L-histidine) individually or together to the feed $[3,162]$. According to Harris et al. [163], the rate of carnosine synthesis in muscle is more affected by $\beta$-alanine than 1-histidine. Chicken meat is liable to oxidative processes that can adversely affect color, taste, and odor. Due to its antioxidant activity, carnosine is important in prolonged meat storage [164]. The importance of $\beta$-alanine in carnosine synthesis was reported by 
Qi et al. [165] and Perin et al. [166]. Chicken meat quality can be improved by antioxidants in feed since, after digestion, they are incorporated into cell membranes and thus protect the tissue from oxidation (i.e., from reactive oxygen species). Carnosine, being a natural dipeptide, is effective in reducing lipid oxidation and maintaining meat quality. Qi et al. [165] found that the addition of $0.5 \%$ carnosine in the chicken feed decreased TBARS (thiobarbituric acid reactive substances) and increased TAOC (total antioxidant capacity) in blood and chicken muscles $(p<0.001)$, improving the meat quality. Similarities were observed in studies by Cong et al. [167] who established that the thigh muscles contained carnosine of 1509, 1539, 1569, and $1617 \mathrm{mg} / \mathrm{kg}$ and increased concentrations of carnosine synthase 1.0, 1.08, 1.15, and $1.22 \mathrm{mg} / \mathrm{kg}$. Kralik et al. [168] investigated the impact of amino acid and $\mathrm{MgO}$ addition on carnosine deposition in chicken meat (Table 3).

Table 3. Effect of treatments on the concentration of carnosine $(\mathrm{mg} / \mathrm{kg})$ in breasts and thigh muscles of broilers.

\begin{tabular}{|c|c|c|c|}
\hline & \multirow{2}{*}{ Treatments } & \multicolumn{2}{|c|}{ Content of Carnosine } \\
\hline & & Breast & Thigh \\
\hline \multirow{6}{*}{ Kralik et.al. (2015) [160] } & $\beta$-alanine $0.0 \%$ & 756.15 & - \\
\hline & L-histidine $0.0 \%$ & 941.58 & - \\
\hline & $\beta$-alanine $0.5 \%$ & 753.29 & - \\
\hline & L-histidine $0.3 \%$ & 1025.22 & - \\
\hline & $\beta$-alanine $1.0 \%$ & 911.01 & - \\
\hline & L-histidine $0.5 \%$ & 1186.06 & - \\
\hline \multirow{4}{*}{ Kralik et. al. (2018) [168] } & Control & 665.47 & 261.19 \\
\hline & $\beta$-alanine $0.5 \%+\mathrm{MgO} 0.24 \%$ & 715.45 & 420.64 \\
\hline & L-histidine $0.25 \%+\mathrm{MgO} 0.24 \%$ & 736.17 & 467.40 \\
\hline & $\beta$-alanine $0.20 \%+$ L-histidine $0.10 \%+\mathrm{MgO} 0.24 \%$ & 1084.25 & 495.01 \\
\hline
\end{tabular}

The authors found an influence of feeding treatments on the technological properties of meat, the carnosine concentration in the breast and thigh muscles as well as the level of TBARS values in fresh and frozen meat [168]. These results are in line with those reported by Soyer et al. [169] and Cong et al. [167,170]. Analysis of carnosine content results in breast muscle tissue showed that carnosine content increased compared to the P1 control group.

\section{Forthcoming Research-Potential Health Benefits and Clinical Use \\ 7.1. Carnosine in Glucose Metabolism/Diabetes}

Type 2 diabetes mellitus is one of the leading public health problems and a global epidemic in modern society. Despite all methods of treatment, which are often insufficient, diabetes is associated with an increased risk of cardiovascular diseases, renal failure, visual impairment, and limb amputations [171]. Known as a natural antioxidant, carnosine has been found to improve metabolic control in different animal models of diabetes, despite the fact that its mechanisms are still not completely known. There are several studies about the effect of carnosine supplementation in animals with metabolic syndrome or diabetes (Table 4). Carnosine in animal models demonstrated protective effects on the development of chronic complications in diabetes [89,172-174]. Treatment of rats with a high-fat high-carbohydrate diet was associated with the development of metabolic syndrome, and carnosine supplementation reduced abdominal obesity, blood pressure values, glucose levels, and normalized total cholesterol and low-density lipoprotein (LDL) levels [175]. Furthermore, carnosine supplementation showed positive effects in mice with diabetic nephropathy by restoring the glomerular ultrastructure, which reduced albuminuria [176]. It was observed that carnosine treatment decreased proteinuria and renal damage in diabetic mice [177], inhibited the production of fibronectin and TGF $\beta$ in 
renal cells [178], and also improved wound healing in diabetes [20]. Similarly, in rat models of type 2 diabetes mellitus, carnosine supplementation decreased serum lipids, creatinine, and urea levels [179].

Table 4. The effects of carnosine in animal models of metabolic syndrome or type 2 diabetes mellitus.

\begin{tabular}{|c|c|c|}
\hline Study Design & Daily Intake of Carnosine & Main Findings of Carnosine Effects \\
\hline $\begin{array}{l}\text { Rats }(\mathrm{n}=40) \text { received conventional diet } \\
\text { (control), high-fat high-carbohydrate diet, } \\
\text { carnosine and conventional diet, or } \\
\text { carnosine and high-fat high-carbohydrate } \\
\text { diet [175] }\end{array}$ & $\begin{array}{l}250 \mathrm{mg} / \mathrm{kg} / \text { daily } \\
\text { intraperitoneal; } 16 \text { weeks }\end{array}$ & $\begin{array}{c}\text {-reduced abdominal obesity, blood } \\
\text { pressure, glucose; } \\
\text {-normalized total cholesterol, LDL level } \\
\text {-no effect on insulin, leptin and } \\
\text { adiponectin concentrations }\end{array}$ \\
\hline $\begin{array}{l}\text { BTBR (Black and Tan, BRachyuric) ob/ob } \\
\text { mice }(\mathrm{n}=35) \text {, a type } 2 \text { diabetes model } \\
\text { with a phenotype like advanced human } \\
\text { diabetes nephropathy [176] }\end{array}$ & $\begin{array}{l}45 \mathrm{mg} / \mathrm{kg} \text { body weight } \\
\text { dissolved in drinking water }\end{array}$ & $\begin{array}{c}\text {-improved glucose metabolism, } \\
\text { albuminuria and restored the glomerular } \\
\text { ultrastructure }\end{array}$ \\
\hline $\begin{array}{l}\text { Effect of carnosine on renal function, } \\
\text { oxidation and glycation products in the } \\
\text { kidneys of high-fat } \\
\text { diet/streptozotocin-induced diabetic rats } \\
\qquad(\mathrm{n}=24)[179]\end{array}$ & $\begin{array}{l}250 \mathrm{mg} / \mathrm{kg} \text { body weight; } \\
\text { intraperitoneal, } 5 \text { times a } \\
\text { week; } 4 \text { weeks }\end{array}$ & $\begin{array}{c}\text {-decreased serum lipids, creatinine, and } \\
\text { urea levels, oxidation products of lipids } \\
\text { and proteins, advanced glycation end } \\
\text { products (AGEs) levels }\end{array}$ \\
\hline
\end{tabular}

Carnosine has been demonstrated to decrease the circulating Insulin Like Growth Factor Binding Protein 1 (IGFBP1) levels and the liver expression of IGFBP1, possibly directly by suppressing HIF-1a-mediated IGFBP1 induction and in an indirect manner by increasing circulating insulin level followed by a decrease in the blood glucose levels and increased plasma levels or IGF1. Reduction of IGFBP1 in diabetes through both insulin-dependent and insulin-independent pathways is a novel mechanism by which carnosine contributes to the improvement of the metabolic control in diabetes [180]. Several human studies involving patients with type 2 diabetes mellitus have also shown positive effects of carnosine supplementation (Table 5). In a randomized double-blind study by Karkabounas et al. [181], obese type 2 diabetic patients were either supplemented daily with $\alpha$-lipoic acid, carnosine, and thiamine or placebo. Results showed reduced glucose and $\mathrm{HbA} 1 \mathrm{c}$ levels after supplementation, probably by increasing insulin production from pancreas. In another randomized, double-blind, placebo-controlled clinical trial, patients with type 2 diabetes mellitus received either placebo or carnosine. Patients who received carnosine had a significant decrease in fat mass, fasting blood glucose, glycated hemoglobin, and serum levels of triglycerides [129]. On the other hand, carnosine supplementation resulted in a decrease in $\mathrm{HbA1c}$, but had no effect on cholesterol, fasting blood sugar, triglycerides, and high density lipoprotein -C (HDL-C) [182]. These studies are promising, but more research is needed on larger samples. As the number of patients with diabetes and metabolic syndrome is increasing, this is an interesting area for future research.

Table 5. The effects of carnosine in patients with metabolic syndrome or type 2 diabetes mellitus.

\begin{tabular}{ccc}
\hline Study Design & Daily Intake of Carnosine & Main Findings of Carnosine Effects \\
\hline $\begin{array}{c}\text { Obese type 2 diabetic patients }(\mathrm{n}=82) \text { were } \\
\text { either supplemented daily with } \alpha \text {-lipoic acid, } \\
\text { carnosine and thiamine [181] }\end{array}$ & $\begin{array}{c}7 \mathrm{mg} \alpha \text {-lipoic acid } / \mathrm{kg} \text { body weight, } \\
6 \mathrm{mg} \text { carnosine } / \mathrm{kg} \text { body weight, } \\
\text { and } 1 \mathrm{mg} \text { thiamine } / \mathrm{kg} \text { body weight } \\
\text { or placebo for } 8 \text { weeks }\end{array}$ & $\begin{array}{c}\text {-reduced glucose and HbA1c levels, } \\
\text { probably by increasing insulin production } \\
\text { from pancreas }\end{array}$ \\
$\begin{array}{c}\text { Patients with type 2 diabetes mellitus }(\mathrm{n}=54) \\
\text { divided into two groups, received either } \\
\text { placebo or carnosine [129] }\end{array}$ & $\begin{array}{c}\text { L carnosine 2 capsules of } 500 \mathrm{mg} \\
\text { each for 12 weeks. }\end{array}$ & $\begin{array}{c}\text {-decrease in fat mass, fasting blood glucose, } \\
\text { glycated hemoglobin and serum levels of } \\
\text { triglycerides }\end{array}$ \\
\hline
\end{tabular}




\subsection{Carnosine in Cardiovascular Disorders (Atherosclerosis, Heart Failure)}

Cardiovascular disease remains the leading cause of death globally [183]. There are many factors that promote the development of endothelial dysfunction underlying cardiovascular diseases such as hypercholesterolemia, diabetes mellitus, metabolic syndrome, hypertension, aging (advanced glycation end products), oxidative stress, proinflammatory cytokines, etc. [184]. Due to its anti-inflammatory, antioxidant, anti-glycation, antiischemic, and chelating roles in body, carnosine may be useful in treating cardiovascular diseases [179]. Macrophages have a pivotal function in various diseases associated with oxidative stress and inflammation (atherosclerosis, diabetes) [185], and it is reported that carnosine has beneficial effects on macrophage cells under oxidative stress and inflammation conditions [186]. Carnosine was able to block the formation of catecholaldehyde protein adducts (which have been implicated as causal factors in the etiology of neurodegenerative diseases and cardiac injury from ischemia and diabetes) in isolated human cardiac mitochondria treated with norepinephrine, which can be a therapeutic potential of carnosine in diseases associated with catecholamine-related toxicity [187]. In patients with heart failure who were treated with carnosine for six months, an improvement was seen in the 6-min walk test distance and quality of life by the EQ-5D questionnaire and visual analog scale score (VAS). Furthermore, peak $\mathrm{VO}_{2}$ and peak exercise workload also increased in the treatment group [188].

The studies shown in Table 6 were performed on a small sample and mainly on animal models or in vitro, so it is necessary to further investigate the effect of carnosine in randomized controlled clinical trials.

Table 6. The effects of carnosine in cardiovascular diseases.

\begin{tabular}{|c|c|c|}
\hline Study Design & $\begin{array}{l}\text { Daily Intake of Carnosine/Cells } \\
\text { Exposure with Carnosine }\end{array}$ & Main Findings of Carnosine Effects \\
\hline $\begin{array}{c}\text { Carnosine was tested for its ability to } \\
\text { counteract oxidative stress in } \\
\text { macrophages [186] }\end{array}$ & Carnosine $(5,10,20 \mathrm{mM})$ & $\begin{array}{l}\text {-multimodal mechanism of action on } \\
\text { macrophage cells under oxidative } \\
\text { stress and inflammation conditions }\end{array}$ \\
\hline $\begin{array}{l}\text { Mitochondria from myocardial atrial } \\
\text { samples were isolated and incubated } \\
\text { for } 3 \mathrm{~h} \text { at } 37^{\circ} \mathrm{C} \text { with } 75-\mu \mathrm{M} \\
\text { norepinephrine } \mathrm{NE} \text { ) and increasing } \\
\text { concentrations of carnosine }(1,2.5,5 \text {, } \\
\text { 10, and } 25 \mathrm{mM} \text { ) [187] }\end{array}$ & Carnosine (1 mM) & $\begin{array}{l}\text {-carnosine block formation of } \\
\text { catecholaldehyde protein adducts in } \\
\text { isolated human cardiac mitochondria } \\
\text { treated with NE }\end{array}$ \\
\hline $\begin{array}{l}\text { Rats }(\mathrm{n}=24) \text { were treated with } \\
\text { carnosine or carnosine + vitamin E. } \\
\text { On the 8th day of treatment, rats } \\
\text { were injected with a single dose of } \\
\text { doxorubicin [189] }\end{array}$ & $\begin{array}{l}\text { Carnosine } 250 \mathrm{mg} / \mathrm{kg} / \text { day i.p. or } \\
\text { carnosine + vit } \mathrm{E}(200 \mathrm{mg} / \mathrm{kg} \text { ) once } \\
\text { every } 3 \text { days; i.m.); for } 12 \text { days }\end{array}$ & $\begin{array}{l}\text {-carnosine and especially in } \\
\text { combination with vitamin E, protect } \\
\text { against doxorubicin-induced toxicity } \\
\text { in heart, liver, and kidney tissues of } \\
\text { rats }\end{array}$ \\
\hline $\begin{array}{l}\text { Patients }(\mathrm{n}=50) \text { with stable chronic } \\
\text { heart failure }(\mathrm{CHF}) \text { and severe } \\
\text { left-ventricular systolic dysfunction } \\
\text { on optimal medical therapy were } \\
\text { randomized 1:1 to receive oral or } \\
\text { dispersible carnosine or standard } \\
\text { treatment [188] }\end{array}$ & $\begin{array}{l}\text { Carnosine } 500 \mathrm{mg} \text { once a day; } \\
6 \text { months }\end{array}$ & $\begin{array}{l}\text {-beneficial effects on exercise } \\
\text { performance and quality of life in } \\
\text { stable CHF }\end{array}$ \\
\hline
\end{tabular}

\subsection{Carnosine in Neurological Disorders}

According to previous research, overproduction of reactive oxygen (ROS) and nitrogen species (RNS) and failure of balancing the effects of endogenous antioxidant defenses contribute to the oxidation of mitochondrial proteins, lipids, deoxyribonukleic/ribonucleic acid, and thus the development of neurodegenerative diseases $[190,191]$. Today, the ef- 
fectiveness of carnosine on various neurological and mental disorders (like Alzheimer's diseases, acute ischemic stroke, schizophrenia, depression) is being increasingly examined [192-195]. Carnosine has been shown to have positive effects, strengthening the endogenous antioxidant protection of the organism [196], increased activity of superoxide dismutase in erythrocytes [197], decrease in hydroperoxides in lipoproteins of blood plasma, considerably increased the resistance low-density and very-low-density lipoproteins against $\mathrm{Fe}^{2+}$-induced oxidation as well as a reduction in the amount of oxidized proteins in blood plasma [197]. Altogether, carnosine, through its reduction of oxidative stress, decreases neurologic symptoms, negative consequences of therapy, and improves cognitive functions of the brain in patients [192-194].

The mechanisms of carnosine-induced neuroprotection in brain ischemia have been described in several animal studies. According to the results of a meta-analysis of eight animal studies exploring the effects of carnosine on ischemic stroke, there was a $29.4 \%$ average reduction in infarct volume with a clear dose-dependent effect (38.1\% reduction on $1000 \mathrm{mg} / \mathrm{kg}$ dose compared with $13.2 \%$ for doses less than $500 \mathrm{mg} / \mathrm{kg}$ ) [198]. In order to clarify the effects of carnosine on brain ischemia, several mechanisms have been proposed. A pre-treatment comprising a formula NT-020 (a pill-based nutraceutical containing a proprietary formulation of blueberry, carnosine, green tea, vitamin D3 and Biovin) for a duration of two weeks before transient occlusion of the middle cerebral artery in rats resulted in the reduction of motor asymmetry and neurological dysfunction, decreasing the striatum ischemic area. In comparison to placebo supplemented rats, this was accompanied with a respective one-fold and three-fold increase in neurogenesis in the subventricular zone and ischemic striatal penumbra, which might be ascribed to growth factors including glial cell-derived neurotrophic factor, the stem cell factor (SCF), and the vascular endothelial growth factor (VEGF) [199]. There is another mechanism related to the anti-inflammatory properties of carnosine. In a permanent cerebral ischemia model, the dose-dependent supplementation with a beef decoction (with $63 \%$ of its amino acid content being carnosine) resulted in the downregulation of the expression of proinflammatory cytokines IL-6, TNF- $\alpha$, and interferon- $\gamma($ IFN- $\gamma)$ as well as the upregulation of the expression of anti-inflammatory cytokine IL-4 [200]. It was also demonstrated that the carnosine treatment before brain ischemia reduced lipid peroxidation and enhanced antioxidant activity in the hippocampus and prefrontal cortex, inhibited mRNA expression of mediators of apoptosis (apoptosisinducing factor, AIF, caspase 3), and upregulated mRNA expression of STAT3, which is an important regulator of anti-apoptotic factors [80,201,202]. On the other hand, anserine ( $\beta$-alanyl-3-methyl-L-histidine) and $\mathrm{N}$-acetyl carnosine, which are carnosine analogues, did not reduce infarct volume or improve neurologic function in a mouse model of focal cerebral ischemia [203].

Some animal studies propose that the brain histaminergic system is connected with epilepsy [204,205]. After being supplemented for 45 days with a compound comprising homocarnosine, carnosine, and anserine, the animals displayed significantly increased anti-convulsant activity after the epilepsy was induced using pentylenenetrazol (PTZ) as well as reduced lipid peroxidation and increased antioxidant concentrations [206]. Carnosine dose-dependently reduced seizure severity and prolonged the latency for myoclonic jerks after the beginning of seizures. Carnosine also increased the levels of histamine in the hippocampus and cortex that were decreased after administration of PTZ [207-210]. Furthermore, carnosine precursor L-histidine was a beneficial adjuvant to the anti-epileptic drugs carbamazepime and phenytoin in the case of mouse models of maximal electroshockinduced seizures [211]. In addition to the carnosine-histidine-histamine pathway, carnosine can also have a direct impact on CA1 pyramidal neurons [212] or act as a precursor for the neurotransmitter GABA [213] and in that manner, mediates its anti-convulsant properties.

Alzheimer's disease (AD) is a neurodegenerative disease characterized by loss of cognitive abilities [214]. An increasing body of evidence shows that supplementation with carnosine, anserine, or its precursors could impede AD pathogenesis at the neurotoxic protein formation level. For example, mice with $\mathrm{AD}$ and mice with knockout of beta secretase 1 , 
a key enzyme in the clearance of $\beta$-amyloid, exhibit reduced carnosine brain content [215]. In addition, $\beta$-alanine levels may be important in the modulation of spatial memory [216]. The addition of anserine, a methylated form of carnosine to AD-model mice for eight weeks ameliorated pericyte coverage on endothelial cells, reduced chronic neuroinflammation of glial cells, and thus improved their memory function [217]. Several studies have reported that carnosine supplementation reduced $\beta$-amyloid cumulation in the hippocampus of a transgenic mouse model of AD [218]. The finding that metabolic disturbance plays an important role in $\mathrm{AD}$ pathogenesis is supported by the discovery that advanced glycation end-products (AGEs) found in $\beta$-amyloid plaques [219] and pre-incubation of $\beta$-amyloid with carbohydrates promoted transformation of soluble $\beta$-amyloid into insoluble deposits, accelerating the $\beta$-amyloid aggregation [220]. Several studies have proposed that the carnosine mechanisms in neurodegeneration and in metabolism might overlap. These mechanisms encompass decreasing oxidative stress with concomitant strengthening of the antioxidant system and anti-inflammatory response or enhanced activity of acetylcholinesterase [221-223]. Carnosine has a protective effect on BV-2 microglia cells by reducing the levels of reactive $\mathrm{NO}$ and $\mathrm{O}_{2}$ species, and the expression of inducible nitric oxide synthase (iNOS) and NADPH oxidase. Furthermore, it reduces the secretion of proinflammatory cytokines such as IL- $1 \beta$, and increases the release of transforming growth factor-beta 1 (TGF- $\beta 1$ ), and through these mechanisms, prevents neuronal dysfunction in the brain of a person with AD [124]. Interestingly, Hata et al. [224] examined the association between serum concentrations of $\beta$-alanine, carnosine, and anserine metabolites, and the risks of dementia in the general elderly Japanese population and concluded that higher carnosine/anserine intake may be beneficial for dementia prevention. Taking into account that BA/carnosine supplementation improves cognitive function in elderly people, one may hypothesize that carnosine intake may also have an important beneficiary effect in people with AD or dementia of other causes. Only four clinical trials were identified in PubMed that evaluated the effects of carnosine supplementation in dementia. In the group of mild cognitive impaired (MCI) people, anserine/carnosine intake improved the score in the global Clinical Dementia Rating compared to the placebo taking group, which was even more prominent within the subgroup of APOE4(+) subjects with MCI [225]. Anserine has also been shown to protect elderly persons with $\mathrm{MCI}$ from cognitive decline. Protection occurs due to suppression of myeloperoxidase-mediated neuroinflammatory responses due to the scavenging properties of anserine toward hypochlorous acid [226]. On the other hand, treatment with a formula containing carnosine did not exhibit a significant effect in a population of patients with moderate $\mathrm{AD}$ [227]. No data are available on the carnosine intake and $\mathrm{AD}$ or dementia course/outcome in a human population and there is a lack of any randomized controlled trials that would confirm the beneficiary effects of carnosine and its precursors on cognitive function or the mechanisms of neuronal function, observed in animal models.

\subsection{Carnosine in Malignant Diseases}

The positive effects of carnosine in the treatment of tumors are increasingly being observed. It is likely that L-carnosine inhibits splenic sympathetic nerve activity and proliferation in rats as well as the multiplication and growth of cancer cells by increasing the natural killer cells (NK cells) responsible for the natural cytotoxicity of the organism [30]. Carnosine combined with radiotherapy reduced the side effects of radiation, injury of skin and intoxication of the organism, increased immunity, decreased the level of reactive oxygen species, and increased the activity of mitochondrial superoxide dismutase in tumor cells [228]. Since one of the biggest challenges today is certainly the treatment of malignant tumors, the fact that carnosine may have a role in this challenge is supported by the studies listed in Table 7. It is known that cancer cells have a high dependence on glycolysis for their production of adenosine triphosphate (ATP), while carnosine has the ability to inhibit glycolysis and thus achieve an antitumor effect $[229,230]$. Hipkiss et al. [231] discussed the potential mechanisms through which carnosine acts to inhibit glycolysis, and these are: 
influence on glycolytic enzymes, metabolic regulatory activities, redox biology, protein glycation, glycoxalase activity, apoptosis, gene expression, and metastasis. Carnosine inhibits glioblastoma growth, but independent of PI3K/Akt/mTOR signaling with a significant reduction of Akt phosphorylation in the U87 glioblastoma cell line. In addition, cell viability was reduced only in the presence of carnosine [232]. Carnosine has an effect in bladder cancer by stopping the G1 phase cell cycle by increasing p21WAF1 expression and decreasing cyclin/CDK complexes. Furthermore, it has an effect on promoter-matrix metalloproteinase-9 (MMP-9), which is a key regulator and participates in the metastasis of bladder cancer cells. Carnosine suppresses the binding of transcription factors NF-kB, Sp-1, and AP-1 to the MMP-9 promoter. In addition, it inhibits angiogenesis by suppressing VEGFR-2-mediated signaling pathways such as extracellular signal-regulatedprotein kinase (ERK), AKT, and nitric oxide synthase (eNOS) [233]. Carnosine inhibits metastatic cell adhesion and extravasation by suppressing nuclear factor $\mathrm{kB}(\mathrm{NF}-\mathrm{KB})$ signaling pathway activation in human colon cancer cells and umbilical vein cells [234]. Carnosine decreased expression of hypoxia inducible factor 1 alpha (HIF-1 $\alpha$ ) in human colon cancer cells, which is a major cause of resistance to drugs. Furthermore, in combination with 5-fluorouracil (5FU), it lowers the expression of some chemoresistance markers $[235,236]$. Carnosine retards senescence of human peritoneal mesothelial cells and inhibits progression of ovarian cancer cells, probably by inhibiting oxidative stress. Taken together, for these beneficial effects of carnosine, further studies to elucidate the exact mechanisms of its action are justified [237].

Table 7. Overview of studies of the mechanism of action of carnosine in malignant diseases.

\begin{tabular}{|c|c|c|c|}
\hline Study Design & Tumors & Cells Exposure with Carnosine & $\begin{array}{l}\text { Main Findings of Carnosine } \\
\text { Effects }\end{array}$ \\
\hline $\begin{array}{c}\text { Experimental } \\
\text { Two cell lines (U87 and T98 G) [232] }\end{array}$ & Glioblastoma & $\begin{array}{l}\text { Carnosine }(50 \mathrm{mM}) \text {, the PI3K } \\
\text { inhibitor Ly-294,002 }(5 \mu \mathrm{M}) \text {, the } \\
\text { mTORC1 inhibitor rapamycin }(25 \\
\mathrm{nM}) \text { and combinations of the } \\
\text { compounds for } 24 \mathrm{~h}\end{array}$ & $\begin{array}{l}\text {-reduces Akt phosphorylation } \\
\text { in the U87 cell line }\end{array}$ \\
\hline $\begin{array}{c}\text { Experimental } \\
\text { In EJ bladder cancer cells and } \\
\text { EJ-xenografted BALB/c nude mice } \\
(\mathrm{n}=7 \text { per each group) }[233]\end{array}$ & Bladder cancer & $\begin{array}{l}\text { Carnosine }(0,10,20,50 \text {, and } \\
100 \mathrm{mM}) \text { for } 24 \mathrm{~h} \text {. } \\
\text { Carnosine }(0,5,10 \mathrm{mg} / \mathrm{kg}) \text { were } \\
\text { administered by oral gavage daily. } \\
\text { Then the efficacy was compared } \\
\text { with that of } 5 \mathrm{mg} / \mathrm{kg} \text { cisplatin, the } \\
\text { positive control. }\end{array}$ & $\begin{array}{l}\text {-stops the G1 phase cell cycle, } \\
\text { suppresses the binding of } \\
\text { transcription factors on the } \\
\text { MMP-9 promoter } \\
\text {-in xenograft tumors exhibited } \\
\text { antitumor activity equivalent to } \\
\text { cisplatin, but no weight loss } \\
\text { occurred in carnosine-treated } \\
\text { mice. }\end{array}$ \\
\hline $\begin{array}{c}\text { Experimental } \\
\text { The HCT-116 human colorectal } \\
\text { cancer cell line } \\
\text { The EA.hy926 human umbilical } \\
\text { vein endothelial cell line } \\
\text { Cells treated with sterile water } \\
\text { served as the control }[235,236]\end{array}$ & Colorectal cancer & $\begin{array}{c}\text { Carnosine }(0.5,1 \text { or } 5 \mathrm{mM}) \text { was } \\
\text { added EA.hy } 926 \text { cells for } 12,24 \text {, } \\
48 \mathrm{~h} \text {. } \\
\text { HCT-116 cells were treated with } \\
1 \mu \mathrm{g} / \mathrm{mL} \\
\text { lipopolysaccharide, then } 0.5,1 \text { or } \\
5 \mathrm{mM} \text { carnosine combined with } \\
1 \mu \mathrm{g} / \mathrm{mL} \text { LPS was added and cells } \\
\text { were incubated for } 24 \mathrm{~h}\end{array}$ & $\begin{array}{c}\text {-suppress adhesion of HCT-116 } \\
\text { cells to EA.hy926 cells and } \\
\text { extravasation. } \\
\text {-inhibits the NF-kB signaling } \\
\text { pathway activation } \\
\text {-reduced the permeability of } \\
\text { EA.hy926 cell-cell junctions } \\
\text {-inhibited HCT-116 cell } \\
\text { adhesion to EA.hy926 cells }\end{array}$ \\
\hline $\begin{array}{c}\text { Experimental } \\
\text { Primary human peritoneal } \\
\text { mesothelial cells, three ovarian } \\
\text { cancer cell lines: A2780, OVCAR-3 } \\
\text { and SKOV-3 [237] }\end{array}$ & Ovarian cancer & L-carnosine (20 mM) & $\begin{array}{l}\text {-inhibits mitochondria-related } \\
\text { oxidative stress }\end{array}$ \\
\hline
\end{tabular}




\subsection{Carnosine and Vascular Function}

Nitric oxide (NO) is a key inter- and intracellular mediator that plays an important role in the maintenance of vascular tone, platelet aggregation, and endothelial viability [238]. Different studies have shown a contradictory effect of carnosine on NO release and activity. While some studies indicate a stimulating effect of carnosine on NO formation, the results of some other studies are quite the opposite, indicating the inhibitory effect. For example, carnosine, in the presence of NADPH, stimulated activity of NO synthase as measured by soluble guanylate cyclase [239]. In cultured endothelial cells [240] carnosine facilitates NO production at concentrations higher than $5 \mathrm{mM}$, and the mechanisms may include a carnosine-induced rise in free calcium levels.

On the other hand, carnosine exhibited an inhibitory effect on NO-dependent activation of guanylate cyclase [241], which is attributed to NO interaction with the Fe-heme prosthetic group, suggesting that carnosine could interact directly with NO. Nicoletti at el. demonstrated a direct interaction of carnosine with $\mathrm{NO}$ and a correlation was found between cellular protection and NO free radical scavenging activity of carnosine in primary astroglia cell cultures [242].

NO production induced by dietary carnosine may locally dilate blood vessels, but may not reduce systemic blood pressure since reduced blood pressure in rats was noticed after intravenously administered a high dose $(33.3 \mathrm{mg} / \mathrm{kg})$ of carnosine. Furthermore, carnosine causes endothelium-independent vasodilation in isolated rat aorta, which emphasizes its functional importance in vasodilation despite damaged endothelium. These results are the opposite of those highlighted by O'Dowd et al. [243], demonstrating vasoconstrictive effect of carnosine on rabbit saphenous vein, suggesting a diverse effect of carnosine on endothelial cells in different blood vessels. While carnosine causes vasodilation of aortas, at least in part, through increased production of cGMP [244] (since guanylate cyclase inhibition by methylene blue significantly decreases it), it is suggested that a serotonin receptor may mediate vasoconstriction [245]. Similar receptors are lacking in the aorta.

In conclusion, carnosine may express both inhibitory and stimulatory effect on $\mathrm{NO}$ production and metabolism depending on the vascular bed, and it is still unclear under what conditions which mechanism is activated. Carnosine may also have important vascular features under conditions in which carnosine may be driven from tissue where its concentration is high (e.g., from muscle during exercise). Furthermore, carnosine supplementation or pharmacologic inhibition of carnosinase could be an efficient approach for blood pressure reduction in the treatment of hypertension [244].

Evidence from animal studies showed that carnosine supplementation may reduce body weight, blood pressure level, serum lipid levels, and atherosclerotic plaque instability, thus inhibiting the development and/or progression of hypertension and atherosclerosis $[110,135,174,246,247]$. However, well controlled human clinical trials investigating the role of carnosine in preserving and improving cardiovascular health are still scarce. A randomized placebo-controlled trial reported that 4-month treatment with a dietary supplement containing cinnamon, chromium, and carnosine (1.2 g/day) decreased fasting blood glucose and increased fat-free mass in overweight or obese pre-diabetic subjects [248]. Furthermore, other randomized controlled trial demonstrated that L-carnosine $(500 \mathrm{mg} / \mathrm{d})$, added to conventional therapy for six months, significantly improved cardiopulmonary exercise test and the 6-min walking test, but not left-ventricular ejection fraction in patients with chronic heart failure [188]. The fact that endothelial dysfunction, characterized by a loss of vasodilator and anti-inflammatory properties of endothelium, presents one of the earliest events in the pathological development of cardiovascular diseases [249], leads to the question of whether carnosine supplementation has the potential to modulate endothelium and vascular function, respectively. Such potential interaction between carnosine supplementation and vascular endothelium-dependent responses is still under investigated in both patients and healthy population. Evidence from a limited number of studies (mostly in animals) suggest that the potential of carnosine supplementation in improving and enhancing the cardiometabolic health of cardiovascular and diabetic patients lies in 
its anti-inflammatory and anti-oxidative properties [102,135,201]. However, a literature search that included the effect of carnosine (an over-the-counter food supplement) on endothelial function in humans did not show any study examining this issue. There is only a published protocol (but still not published results) for a randomized, double-blind, placebo-controlled trial on the effect of carnosine on cardiometabolic health in patients with pre-diabetes and type 2 diabetes, which will include endothelial function assessment by using non-invasive peripheral arterial tomography [146]. Therefore, it is expected that well-designed and controlled human clinical trials with large sample sizes will include functional assessment of vascular reactivity and endothelial function will provide valuable insights on the effect of carnosine on vasculature and endothelium in both cardiovascular patients (and/or population with increased cardiovascular risk) and healthy populations.

\section{Conclusions}

The objective of this review was to provide a state-of-the-art overview of the science of carnosine's role in health and disease. As an endogenous substance, carnosine is easily absorbed by the digestive tract and can cross the blood-brain barrier [250,251]. Importantly, the equilibrium between carnosine and its constituent amino acids in vascular tissue may represent a new and novel mechanism for the modulation of vascular tone and function related to cardiovascular diseases. Since increased oxidative stress level and endothelial inflammation and activation (endothelium-leukocyte interaction) are the culprit of endothelial dysfunction development in various cardiovascular diseases [184,252], it is reasonable to assume that carnosine supplementation could have a beneficial effect on endothelial function, which would be manifested in part as improved vascular reactivity in both the macro- and microcirculation. Thus, investigation of its antioxidative properties in cardiometabolic diseases seems to be the major direction for forthcoming research activity, particularly in the form of dietary intake such as in functional food.

Author Contributions: Conceptualization, I.J. and I.D. Writing-original draft preparation, I.J., N.K. (Nikolina Kolobarić), A.S. (Ana Stupin), A.M., N.K. (Nataša Kozina), Z.M., M.M., P.Š., M.S., Ž.B.Ć., K.S.-R., A.K., A.L., L.K., G.K., Z.K., A.S. (Aleksandar Széchenyi), M.J., O.G., M.M.-K. and I.D. Writing-review and editing, I.J. and I.D. Supervision, I.D. All authors have read and agreed to the published version of the manuscript.

Funding: This study was supported by the European Structural and Investment Funds grant for the Croatian National Scientific Center of Excellence for Personalized Health Care, University of Josip Juraj Strossmayer Osijek (grant \#KK.01.1.1.01.0010).

Institutional Review Board Statement: Not applicable.

Informed Consent Statement: Not applicable.

Data Availability Statement: Data sharing not applicable.

Conflicts of Interest: The authors declare no conflict of interest.

\section{References}

1. Gulewitsch, W.; Amiradžibi, S. Ueber das Carnosin, eine neue organische Base des Fleischextractes. Berichte der Dtsch. Chem. Gesellschaft 1900, 33, 1902-1903. [CrossRef]

2. Aristoy, M.C.; Toldrá, F. Histidine dipeptides HPLC-based test for the detection of mammalian origin proteins in feeds for ruminants. Meat Sci. 2004, 67, 211-217. [CrossRef]

3. Boldyrev, A.A.; Aldini, G.; Derave, W. Physiology and Pathophysiology of Carnosine. Physiol. Rev. 2013, 93, 1803-1845. [CrossRef]

4. Chasovnikova, L.V.; Formazyuk, V.E.; Sergienko, V.I.; Boldyrev, A.A.; Severin, S.E. The antioxidative properties of carnosine and other drugs. Biochem. Int. 1990, 20, 1097-1103.

5. Bellia, F.; Vecchio, G.; Cuzzocrea, S.; Calabrese, V.; Rizzarelli, E. Neuroprotective features of carnosine in oxidative driven diseases. Mol. Aspects Med. 2011, 32, 258-266. [CrossRef] [PubMed]

6. Xing, L.; Chee, M.E.; Zhang, H.; Zhang, W.; Mine, Y. Carnosine-a natural bioactive dipeptide: Bioaccessibility, bioavailability and health benefits. J. Food Bioact. 2019, 5, 8-17. [CrossRef] 
7. Vistoli, G.; Straniero, V.; Pedretti, A.; Fumagalli, L.; Bolchi, C.; Pallavicini, M.; Valoti, E.; Testa, B. Predicting the physicochemical profile of diastereoisomeric histidine-containing dipeptides by property space analysis. Chirality 2012, 24, 566-576. [CrossRef] [PubMed]

8. Torreggiani, A.; Tamba, M.; Fini, G. Binding of copper(II) to carnosine: Raman and IR spectroscopic study. Biopolymers 2000, 57, 149-159. [CrossRef]

9. Hipkiss, A.R. Carnosine and Its Possible Roles in Nutrition and Health. Adv. Food Nutr. Res. 2009, 57, 87-154. [PubMed]

10. Ghodsi, R.; Kheirouri, S. Carnosine and advanced glycation end products: A systematic review. Amino Acids 2018, 50, 1177-1186. [CrossRef]

11. Kim, M.Y.; Kim, E.J.; Kim, Y.-N.; Choi, C.; Lee, B.-H. Effects of $\alpha$-lipoic acid and L-carnosine supplementation on antioxidant activities and lipid profiles in rats. Nutr. Res. Pract. 2011, 5, 421. [CrossRef]

12. Ma, X.Y.; Jiang, Z.Y.; Lin, Y.C.; Zheng, C.T.; Zhou, G.L. Dietary supplementation with carnosine improves antioxidant capacity and meat quality of finishing pigs. J. Anim. Physiol. Anim. Nutr. 2010, 94, e286-e295. [CrossRef]

13. Derave, W.; Everaert, I.; Beeckman, S.; Baguet, A. Muscle Carnosine Metabolism and $\beta$-Alanine Supplementation in Relation to Exercise and Training. Sport. Med. 2010, 40, 247-263. [CrossRef] [PubMed]

14. Decker, E.A.; Faraji, H. Inhibition of lipid oxidation by carnosine. J. Am. Oil Chem. Soc. 1990, 67, 650-652. [CrossRef]

15. Ferraris, R.P.; Diamond, J.; Kwan, W.W. Dietary regulation of intestinal transport of the dipeptide carnosine. Am. J. Physiol. Liver Physiol. 1988, 255, G143-G150. [CrossRef]

16. Gardner, M.L.; Illingworth, K.M.; Kelleher, J.; Wood, D. Intestinal absorption of the intact peptide carnosine in man, and comparison with intestinal permeability to lactulose. J. Physiol. 1991, 439, 411-422. [CrossRef]

17. Fernández-García, E.; Carvajal-Lérida, I.; Pérez-Gálvez, A. In vitro bioaccessibility assessment as a prediction tool of nutritional efficiency. Nutr. Res. 2009, 29, 751-760. [CrossRef]

18. Park, Y.J.; Volpe, S.L.; Decker, E.A. Quantitation of Carnosine in Humans Plasma after Dietary Consumption of Beef. J. Agric. Food Chem. 2005, 53, 4736-4739. [CrossRef]

19. Marcolini, E.; Babini, E.; Bordoni, A.; Di Nunzio, M.; Laghi, L.; Maczó, A.; Picone, G.; Szerdahelyi, E.; Valli, V.; Capozzi, F. Bioaccessibility of the Bioactive Peptide Carnosine during in Vitro Digestion of Cured Beef Meat. J. Agric. Food Chem. 2015, 63, 4973-4978. [CrossRef] [PubMed]

20. Ansurudeen, I.; Sunkari, V.G.; Grünler, J.; Peters, V.; Schmitt, C.P.; Catrina, S.-B.; Brismar, K.; Forsberg, E.A. Carnosine enhances diabetic wound healing in the $\mathrm{db} / \mathrm{db}$ mouse model of type 2 diabetes. Amino Acids 2012, 43, 127-134. [CrossRef] [PubMed]

21. Boldyrev, A.A.; Stvolinsky, S.L.; Fedorova, T.N.; Suslina, Z.A. Carnosine As a Natural Antioxidant and Geroprotector: From Molecular Mechanisms to Clinical Trials. Rejuvenation Res. 2010, 13, 156-158. [CrossRef]

22. Maherani, B.; Arab-Tehrany, E.; Kheirolomoom, A.; Cleymand, F.; Linder, M. Influence of lipid composition on physicochemical properties of nanoliposomes encapsulating natural dipeptide antioxidant l-carnosine. Food Chem. 2012, 134, 632-640. [CrossRef]

23. Bellia, F.; Vecchio, G.; Rizzarelli, E. Carnosine derivatives: New multifunctional drug-like molecules. Amino Acids 2012, 43 , 153-163. [CrossRef] [PubMed]

24. Bellia, F.; Vecchio, G.; Rizzarelli, E. Carnosinases, Their Substrates and Diseases. Molecules 2014, 19, 2299-2329. [CrossRef]

25. Baye, E.; Ukropcova, B.; Ukropec, J.; Hipkiss, A.; Aldini, G.; de Courten, B. Physiological and therapeutic effects of carnosine on cardiometabolic risk and disease. Amino Acids 2016, 48, 1131-1149. [CrossRef] [PubMed]

26. Pavlin, M.; Rossetti, G.; De Vivo, M.; Carloni, P. Carnosine and Homocarnosine Degradation Mechanisms by the Human Carnosinase Enzyme CN1: Insights from Multiscale Simulations. Biochemistry 2016, 55, 2772-2784. [CrossRef]

27. Peters, V.; Klessens, C.Q.F.; Baelde, H.J.; Singler, B.; Veraar, K.A.M.; Zutinic, A.; Drozak, J.; Zschocke, J.; Schmitt, C.P.; de Heer, E. Intrinsic carnosine metabolism in the human kidney. Amino Acids 2015, 47, 2541-2550. [CrossRef]

28. Peters, V.; Jansen, E.E.W.; Jakobs, C.; Riedl, E.; Janssen, B.; Yard, B.A.; Wedel, J.; Hoffmann, G.F.; Zschocke, J.; Gotthardt, D.; et al. Anserine inhibits carnosine degradation but in human serum carnosinase (CN1) is not correlated with histidine dipeptide concentration. Clin. Chim. Acta 2011, 412, 263-267. [CrossRef] [PubMed]

29. Schön, M.; Mousa, A.; Berk, M.; Chia, W.L.; Ukropec, J.; Majid, A.; Ukropcová, B.; de Courten, B. The Potential of Carnosine in Brain-Related Disorders: A Comprehensive Review of Current Evidence. Nutrients 2019, 11, 1196. [CrossRef]

30. Budzeń, S.; Rymaszewska, J. The biological role of carnosine and its possible applications in medicine. Adv. Clin. Exp. Med. 2013, 22, 739-744.

31. Gariballa, S. Review. Carnosine: Physiological properties and therapeutic potential. Age Ageing 2000, 29, 207-210. [CrossRef]

32. Harris, R.C.; Dunnett, M.; Greenhaff, P.L. Carnosine and taurine contents in individual fibres of human vastus lateralis muscle. J. Sports Sci. 1998, 16, 639-643. [CrossRef]

33. Dunnett, M.; Harris, R.C. High-performance liquid chromatographic determination of imidazole dipeptides, histidine, 1methylhistidine and 3-methylhistidine in equine and camel muscle and individual muscle fibres. J. Chromatogr. B Biomed. Sci. Appl. 1997, 688, 47-55. [CrossRef]

34. Hill, C.A.; Harris, R.C.; Kim, H.J.; Harris, B.D.; Sale, C.; Boobis, L.H.; Kim, C.K.; Wise, J.A. Influence of $\beta$-alanine supplementation on skeletal muscle carnosine concentrations and high intensity cycling capacity. Amino Acids 2007, 32, 225-233. [CrossRef]

35. Kendrick, I.P.; Kim, H.J.; Harris, R.C.; Kim, C.K.; Dang, V.H.; Lam, T.Q.; Bui, T.T.; Wise, J.A. The effect of 4 weeks $\beta$-alanine supplementation and isokinetic training on carnosine concentrations in type I and II human skeletal muscle fibres. Eur. J. Appl. Physiol. 2009, 106, 131-138. [CrossRef] [PubMed] 
36. Suzuki, Y.; Ito, O.; Mukai, N.; Takahashi, H.; Takamatsu, K. High Level of Skeletal Muscle Carnosine Contributes to the Latter Half of Exercise Performance during 30-s Maximal Cycle Ergometer Sprinting. Jpn. J. Physiol. 2002, 52, 199-205. [CrossRef]

37. BLANCQUAERT, L.; EVERAERT, I.; MISSINNE, M.; BAGUET, A.; STEGEN, S.; VOLKAERT, A.; PETROVIC, M.; VERVAET, C.; ACHTEN, E.; DE MAEYER, M.; et al. Effects of Histidine and $\beta$-alanine Supplementation on Human Muscle Carnosine Storage. Med. Sci. Sport. Exerc. 2017, 49, 602-609. [CrossRef]

38. Keytsman, C.; Blancquaert, L.; Wens, I.; Missine, M.; Van Noten, P.; Vandenabeele, F.; Derave, W.; Eijnde, B.O. Muscle carnosine in experimental autoimmune encephalomyelitis and multiple sclerosis. Mult. Scler. Relat. Disord. 2018, 21, 24-29. [CrossRef]

39. Varanoske, A.N.; Hoffman, J.R.; Church, D.D.; Coker, N.A.; Baker, K.M.; Dodd, S.J.; Harris, R.C.; Oliveira, L.P.; Dawson, V.L.; Wang, R.; et al. Comparison of sustained-release and rapid-release $\beta$-alanine formulations on changes in skeletal muscle carnosine and histidine content and isometric performance following a muscle-damaging protocol. Amino Acids 2019, 51, 49-60. [CrossRef]

40. Pandya, V.K.; Sonwane, B.; Rathore, R.; Unnikrishnan, A.G.; Kumaran, S.; Kulkarni, M.J. Development of multiple reaction monitoring assay for quantification of carnosine in human plasma. RSC Adv. 2020, 10, 763-769. [CrossRef]

41. Everaert, I.; Taes, Y.; De Heer, E.; Baelde, H.; Zutinic, A.; Yard, B.; Sauerhöfer, S.; Vanhee, L.; Delanghe, J.; Aldini, G.; et al. Low plasma carnosinase activity promotes carnosinemia after carnosine ingestion in humans. Am. J. Physiol. Physiol. 2012, 302, F1537-F1544. [CrossRef] [PubMed]

42. Manyam, B.V. Cerebrospinal Fluid Amino Compounds in Parkinson's Disease. Arch. Neurol. 1988, 45, 48. [CrossRef] [PubMed]

43. Fontes, J.E.d.N.; Rodriguez-Caturla, M.Y.; Sant'Ana, A.S.; Lopes, T.I.B.; Marsaioli, A.J. Foodomics and storage monitoring of three meat cuts by 1 H NMR. Concepts Magn. Reson. Part A 2018, 47A, e21474. [CrossRef]

44. Solis, M.Y.; Cooper, S.; Hobson, R.M.; Artioli, G.G.; Otaduy, M.C.; Roschel, H.; Robertson, J.; Martin, D.; Painelli, V.S.; Harris, R.C.; et al. Effects of Beta-Alanine Supplementation on Brain Homocarnosine/Carnosine Signal and Cognitive Function: An Exploratory Study. PLoS ONE 2015, 10, e0123857. [CrossRef] [PubMed]

45. Özdemir, M.S.; Reyngoudt, H.; De Deene, Y.; Sazak, H.S.; Fieremans, E.; Delputte, S.; D'Asseler, Y.; Derave, W.; Lemahieu, I.; Achten, E. Absolute quantification of carnosine in human calf muscle by proton magnetic resonance spectroscopy. Phys. Med. Biol. 2007, 52, 6781-6794. [CrossRef]

46. Noblitt, S.D.; Staicu, L.C.; Ackerson, C.J.; Henry, C.S. Sensitive, Selective Analysis of Selenium Oxoanions Using Microchip Electrophoresis with Contact Conductivity Detection. Anal. Chem. 2014, 86, 8425-8432. [CrossRef]

47. Fekete, S.; Guillarme, D.; Sandra, P.; Sandra, K. Chromatographic, Electrophoretic, and Mass Spectrometric Methods for the Analytical Characterization of Protein Biopharmaceuticals. Anal. Chem. 2016, 88, 480-507. [CrossRef]

48. HUANG, Y.; DUAN, J.; ZHANG, J.; CHEN, G. Online Sample Stacking for Determination of Carnosine-Related Peptides by Capillary Electrophoresis. Chinese J. Chromatogr. 2007, 25, 326-332. [CrossRef]

49. Staňová, A.; Marák, J.; Rezeli, M.; Páger, C.; Kilár, F.; Kaniansky, D. Analysis of therapeutic peptides in human urine by combination of capillary zone electrophoresis-electrospray mass spectrometry with preparative capillary isotachophoresis sample pretreatment. J. Chromatogr. A 2011, 1218, 8701-8707. [CrossRef]

50. Zhao, S.; Huang, Y.; Shi, M.; Huang, J.; Liu, Y.-M. Quantification of carnosine-related peptides by microchip electrophoresis with chemiluminescence detection. Anal. Biochem. 2009, 393, 105-110. [CrossRef]

51. Jozanović, M.; Hajduković, M.; Galović, O.; Kralik, G.; Kralik, Z.; Sakač, N.; Medvidović-Kosanović, M.; Sak-Bosnar, M. Determination of anti-oxidative histidine dipeptides in poultry by microchip capillary electrophoresis with contactless conductivity detection. Food Chem. 2017, 221, 1658-1665. [CrossRef] [PubMed]

52. Huang, Y.; Shi, Y.; Duan, J.; Chen, G. Field-amplified on-line sample stacking for determination of carnosine-related peptides by capillary electrophoresis. J. Sep. Sci. 2006, 29, 1026-1030. [CrossRef] [PubMed]

53. Ragab, M.A.A.; El-Kimary, E.I. Recent Advances and Applications of Microfluidic Capillary Electrophoresis: A Comprehensive Review (2017-Mid 2019). Crit. Rev. Anal. Chem. 2020, 1-33. [CrossRef] [PubMed]

54. Lara, F.J.; Airado-Rodríguez, D.; Moreno-González, D.; Huertas-Pérez, J.F.; García-Campaña, A.M. Applications of capillary electrophoresis with chemiluminescence detection in clinical, environmental and food analysis. A review. Anal. Chim. Acta 2016, 913, 22-40. [CrossRef] [PubMed]

55. Clark, A.E.; Kaleta, E.J.; Arora, A.; Wolk, D.M. Matrix-Assisted Laser Desorption Ionization-Time of Flight Mass Spectrometry: A Fundamental Shift in the Routine Practice of Clinical Microbiology. Clin. Microbiol. Rev. 2013, 26, 547-603. [CrossRef]

56. Pisarev, D.; Novikov, O.; Vasiliev, G.; Selyutin, O. Experience in using the MALDI/TOF/MS method in pharmaceutical analysis. Sci. Rep. Belgorod State Univ. Ser. Med. Pharmacy 2012, 18, 1-11.

57. Uenoyama, R.; Miyazaki, M.; Miyazaki, T.; Shigeno, Y.; Tokairin, Y.; Konno, H.; Yamashita, T. LC-ESI-MS/MS quantification of carnosine, anserine, and balenine in meat samples. J. Chromatogr. B 2019, 1132, 121826. [CrossRef]

58. Jozanović, M.; Medvidović-Kosanović, M.; Sak-Bosnar, M. Voltammetric Characterization and Determination of Histidine Dipeptides-Carnosine and Anserine. Int. J. Electrochem. Sci. 2015, 10, 6548-6557.

59. Wu, G. Important roles of dietary taurine, creatine, carnosine, anserine and 4-hydroxyproline in human nutrition and health. Amino Acids 2020, 52, 329-360. [CrossRef]

60. Wu, G. Dietary protein intake and human health. Food Funct. 2016, 7, 1251-1265. [CrossRef]

61. Szterk, A.; Roszko, M. Simultaneous determination of free amino acids, l-carnosine, purine, pyrimidine, and nucleosides in meat by liquid chromatography/single quadrupole mass spectrometry. J. Liq. Chromatogr. Relat. Technol. 2014, 37, 664-680. [CrossRef]

62. Clifford, W.M. The Effect of Cold Storage on the Carnosine Content of Muscle. Biochem. J. 1922, 16, 341-343. [CrossRef] [PubMed] 
63. Sale, C.; Saunders, B.; Harris, R.C. Effect of beta-alanine supplementation on muscle carnosine concentrations and exercise performance. Amino Acids 2010, 39, 321-333. [CrossRef]

64. Harris, R.C.; Wise, J.A.; Price, K.A.; Kim, H.J.; Kim, C.K.; Sale, C. Determinants of muscle carnosine content. Amino Acids 2012, 43, 5-12. [CrossRef] [PubMed]

65. MATTHEWS, J.J.; ARTIOLI, G.G.; TURNER, M.D.; SALE, C. The Physiological Roles of Carnosine and $\beta$-Alanine in Exercising Human Skeletal Muscle. Med. Sci. Sport. Exerc. 2019, 51, 2098-2108. [CrossRef] [PubMed]

66. GOODALL, M.C. Carnosine Phosphate as Phosphate Donor in Muscular Contraction. Nature 1956, 178, 539-540. [CrossRef]

67. Severin, S.E.; Kirzon, M.V.; Kaftanova, T.M. Effect of carnosine and anserine on action of isolated frog muscles. Dokl. Akad. Nauk SSSR 1953, 91, 691-694.

68. Boldyrev, A.A. Carnosine: New concept for the function of an old molecule. Biochem. 2012, 77, 313-326. [CrossRef]

69. Smith, E.C.B. The buffering of muscle in rigor; protein, phosphate and carnosine. J. Physiol. 1938, 92, 336-343. [CrossRef]

70. Deutsch, A.; Eggleton, P. The titration constants of anserine, carnosine and some related compounds. Biochem. J. 1938, 32, $209-211$. [CrossRef]

71. Saunders, B.; Elliott-Sale, K.; Artioli, G.G.; Swinton, P.A.; Dolan, E.; Roschel, H.; Sale, C.; Gualano, B. $\beta$-alanine supplementation to improve exercise capacity and performance: A systematic review and meta-analysis. Br. J. Sports Med. 2017, 51, 658-669. [CrossRef]

72. Culbertson, J.Y.; Kreider, R.B.; Greenwood, M.; Cooke, M. Effects of Beta-Alanine on Muscle Carnosine and Exercise Performance: A Review of the Current Literature. Nutrients 2010, 2, 75-98. [CrossRef]

73. Junge, W.; McLaughlin, S. The role of fixed and mobile buffers in the kinetics of proton movement. Biochim. Biophys. Acta Bioenerg. 1987, 890, 1-5. [CrossRef]

74. Swietach, P.; Youm, J.-B.; Saegusa, N.; Leem, C.-H.; Spitzer, K.W.; Vaughan-Jones, R.D. Coupled Ca ${ }^{2+} / \mathrm{H}^{+}$transport by cytoplasmic buffers regulates local $\mathrm{Ca}^{2+}$ and $\mathrm{H}^{+}$ion signaling. Proc. Natl. Acad. Sci. USA 2013, 110, E2064-E2073. [CrossRef] [PubMed]

75. Baguet, A.; Koppo, K.; Pottier, A.; Derave, W. $\beta$-Alanine supplementation reduces acidosis but not oxygen uptake response during high-intensity cycling exercise. Eur. J. Appl. Physiol. 2010, 108, 495-503. [CrossRef]

76. Dawson, R., Jr.; Biasetti, M.; Messina, S.; Dominy, J. The cytoprotective role of taurine in exercise-induced muscle injury. Amino Acids 2002, 22, 309-324. [CrossRef]

77. Boldyrev, A.A.; Dupin, A.M.; Pindel, E.V.; Severin, S.E. Antioxidative properties of histidine-containing dipeptides from skeletal muscles of vertebrates. Comp. Biochem. Physiol. Part B Comp. Biochem. 1988, 89, 245-250. [CrossRef]

78. Gordon, A.M.; Homsher, E.; Regnier, M. Regulation of Contraction in Striated Muscle. Physiol. Rev. 2000, 80, 853-924. [CrossRef]

79. Batrukova, M.A.; Rubtsov, A.M. Histidine-containing dipeptides as endogenous regulators of the activity of sarcoplasmic reticulum Ca-release channels. Biochim. Biophys. Acta Biomembr. 1997, 1324, 142-150. [CrossRef]

80. Zhang, X.; Song, L.; Cheng, X.; Yang, Y.; Luan, B.; Jia, L.; Xu, F.; Zhang, Z. Carnosine pretreatment protects against hypoxiaischemia brain damage in the neonatal rat model. Eur. J. Pharmacol. 2011, 667, 202-207. [CrossRef] [PubMed]

81. Lamb, G.D.; Stephenson, D.G. Effect of $\mathrm{Mg}^{2+}$ on the control of Ca2+ release in skeletal muscle fibres of the toad. J. Physiol. 1991, 434, 507-528. [CrossRef]

82. Dutka, T.L.; Lamb, G.D. Effect of Carnosine on Excitation-Contraction Coupling in Mechanically-Skinned Rat Skeletal Muscle. J. Muscle Res. Cell Motil. 2004, 25, 203-213. [CrossRef]

83. Dutka, T.L.; Lamboley, C.R.; McKenna, M.J.; Murphy, R.M.; Lamb, G.D. Effects of carnosine on contractile apparatus Ca 2+ sensitivity and sarcoplasmic reticulum Ca 2+ release in human skeletal muscle fibers. J. Appl. Physiol. 2012, 112, 728-736. [CrossRef]

84. Lamont, C.; Miller, D.J. Calcium sensitizing action of carnosine and other endogenous imidazoles in chemically skinned striated muscle. J. Physiol. 1992, 454, 421-434. [CrossRef] [PubMed]

85. Bolitho Donaldson, S.K.; Hermansen, L.; Bolles, L. Differential, direct effects of H+ on Ca2+-activated force of Skinned fibers from the soleus, cardiac and adductor magnus muscles of rabbits. Pflügers Arch. Eur. J. Physiol. 1978, 376, 55-65. [CrossRef] [PubMed]

86. Jones, R.L.; Barnett, C.T.; Davidson, J.; Maritza, B.; Fraser, W.D.; Harris, R.; Sale, C. $\beta$-alanine supplementation improves in-vivo fresh and fatigued skeletal muscle relaxation speed. Eur. J. Appl. Physiol. 2017, 117, 867-879. [CrossRef]

87. Tsugorka, A.; Rios, E.; Blatter, L. Imaging elementary events of calcium release in skeletal muscle cells. Science 1995, $269,1723-1726$. [CrossRef] [PubMed]

88. Tallon, M.J.; Harris, R.C.; Boobis, L.H.; Fallowfield, J.L.; Wise, J.A. The Carnosine Content of Vastus Lateralis Is Elevated in Resistance-Trained Bodybuilders. J. Strength Cond. Res. 2005, 19, 725. [CrossRef] [PubMed]

89. Nagai, K.; Niijima, A.; Yamano, T.; Otani, H.; Okumra, N.; Tsuruoka, N.; Nakai, M.; Kiso, Y. Possible Role of L-Carnosine in the Regulation of Blood Glucose through Controlling Autonomic Nerves. Exp. Biol. Med. 2003, 228, 1138-1145. [CrossRef]

90. Nordsborg, N.; Mohr, M.; Pedersen, L.D.; Nielsen, J.J.; Langberg, H.; Bangsbo, J. Muscle interstitial potassium kinetics during intense exhaustive exercise: Effect of previous arm exercise. Am. J. Physiol. Integr. Comp. Physiol. 2003, 285, R143-R148. [CrossRef] [PubMed]

91. Greene, S.M.; Margolis, F.L.; Grillo, M.; Fisher, H. Enhanced carnosine ( $\beta$-alanyl-L-histidine) breakdown and histamine metabolism following treatment with compound. Eur. J. Pharmacol. 1984, 99, 79-84. [CrossRef]

92. IKEDA, T.; KIMURA, K.; HAMA, T.; TAMAKI, N. Activation of Rabbit Muscle Fructose 1,6-Bisphosphatase by Histidine and Carnosine. J. Biochem. 1980, 87, 179-185. [CrossRef] 
93. Brown, C.E. Interactions among carnosine, anserine, ophidine and copper in biochemical adaptation. J. Theor. Biol. 1981, 88, 245-256. [CrossRef]

94. de Andrade Kratz, C.; de Salles Painelli, V.; de Andrade Nemezio, K.M.; da Silva, R.P.; Franchini, E.; Zagatto, A.M.; Gualano, B.; Artioli, G.G. Beta-alanine supplementation enhances judo-related performance in highly-trained athletes. J. Sci. Med. Sport 2017, 20, 403-408. [CrossRef] [PubMed]

95. Tobias, G.; Benatti, F.B.; de Salles Painelli, V.; Roschel, H.; Gualano, B.; Sale, C.; Harris, R.C.; Lancha, A.H.; Artioli, G.G. Additive effects of beta-alanine and sodium bicarbonate on upper-body intermittent performance. Amino Acids 2013, 45, 309-317. [CrossRef] [PubMed]

96. da Silva, R.P.; de Oliveira, L.F.; Saunders, B.; de Andrade Kratz, C.; de Salles Painelli, V.; da Eira Silva, V.; Marins, J.C.B.; Franchini, E.; Gualano, B.; Artioli, G.G. Effects of $\beta$-alanine and sodium bicarbonate supplementation on the estimated energy system contribution during high-intensity intermittent exercise. Amino Acids 2019, 51, 83-96. [CrossRef] [PubMed]

97. Jordan, T.; Lukaszuk, J.; Misic, M.; Umoren, J. Effect of beta-alanine supplementation on the onset of blood lactate accumulation (OBLA) during treadmill running: Pre/post 2 treatment experimental design. J. Int. Soc. Sports Nutr. 2010, 7, 20. [CrossRef]

98. Everaert, I.; Mooyaart, A.; Baguet, A.; Zutinic, A.; Baelde, H.; Achten, E.; Taes, Y.; De Heer, E.; Derave, W. Vegetarianism, female gender and increasing age, but not CNDP1 genotype, are associated with reduced muscle carnosine levels in humans. Amino Acids 2011, 40, 1221-1229. [CrossRef]

99. Asatoor, A.M.; Bandoh, J.K.; Lant, A.F.; Milne, M.D.; Navab, F. Intestinal absorption of carnosine and its constituent amino acids in man. Gut 1970, 11, 250-254. [CrossRef]

100. Cao, Y.; Xu, J.; Cui, D.; Liu, L.; Zhang, S.; Shen, B.; Wu, Y.; Zhang, Q. Protective effect of carnosine on hydrogen peroxide-induced oxidative stress in human kidney tubular epithelial cells. Biochem. Biophys. Res. Commun. 2021, 534, 576-582. [CrossRef]

101. Halliwell, B.; Gutteridge, J.M.C. Free Radicals in Biology and Medicine; Oxford University Press: Oxford, UK, 2015; ISBN 9780198717478.

102. Pavlov, A.R.; Revina, A.A.; Dupin, A.M.; Boldyrev, A.A.; Yaropolov, A.I. The mechanism of interaction of carnosine with superoxide radicals in water solutions. Biochim. Biophys. Acta Gen. Subj. 1993, 1157, 304-312. [CrossRef]

103. Torreggiani, M.T.A. A pulse radiolysis study of carnosine in aqueous solution. Int. J. Radiat. Biol. 1998, 74, 333-340. [CrossRef] [PubMed]

104. Miller, D. Transition metals as catalysts of "autoxidation" reactions. Free Radic. Biol. Med. 1990, 8, 95-108. [CrossRef]

105. Hartman, P.E.; Hartman, Z.; Ault, K.T. Scavenging of singlet molecular oxygen by imidazole compounds: High and sustained activities of carboxy terminal histidine dipeptides and exceptional activity of imidazole-4-acetic acid. Photochem. Photobiol. 1990, 51, 59-66. [CrossRef] [PubMed]

106. Baran, E.J. Metal complexes of carnosine. Biochemistry 2000, 65, 789-797. [PubMed]

107. Torreggiani, M.; Tamba, A. Hydroxyl radical scavenging by carnosine and $\mathrm{Cu}(\mathrm{II})$-carnosine complexes: A pulse-radiolysis and spectroscopic study. Int. J. Radiat. Biol. 1999, 75, 1177-1188. [CrossRef] [PubMed]

108. Crush, K. Carnosine and related substances in animal tissues. Comp. Biochem. Physiol. 1970, 34, 3-30. [CrossRef]

109. Decker, E.A.; Livisay, S.A.; Zhou, S. A re-evaluation of the antioxidant activity of purified carnosine. Biochemistry 2000, 65, 766-770.

110. Aldini, G.; Orioli, M.; Rossoni, G.; Savi, F.; Braidotti, P.; Vistoli, G.; Yeum, K.-J.; Negrisoli, G.; Carini, M. The carbonyl scavenger carnosine ameliorates dyslipidaemia and renal function in Zucker obese rats. J. Cell. Mol. Med. 2011, 15, 1339-1354. [CrossRef]

111. Klebanov, G.I.; Teselkin, Y.O.; Babenkova, I.V.; Popov, I.N.; Levin, G.; Tyulina, O.V.; Boldyrev, A.A.; Vladimirov, Y.A. Evidence for a direct interaction of superoxide anion radical with carnosine. IUBMB Life 1997, 43, 99-106. [CrossRef]

112. Aydın, A.F.; Küçükgergin, C.; Özdemirler-Erata, G.; Koçak-Toker, N.; Uysal, M. The effect of carnosine treatment on prooxidantantioxidant balance in liver, heart and brain tissues of male aged rats. Biogerontology 2010, 11, 103-109. [CrossRef]

113. Aldini, G.; Facino, R.M.; Beretta, G.; Carini, M. Carnosine and related dipeptides as quenchers of reactive carbonyl species: From structural studies to therapeutic perspectives. BioFactors 2005, 24, 77-87. [CrossRef] [PubMed]

114. Esterbauer, H.; Schaur, R.J.; Zollner, H. Chemistry and biochemistry of 4-hydroxynonenal, malonaldehyde and related aldehydes. Free Radic. Biol. Med. 1991, 11, 81-128. [CrossRef]

115. Carletto, C.; Nicolay, J.F.; Courbebaisse, Y. Courbebaisse Oxidative stress and cutaneous ageing: The 'toxic second messengers' concept and an interesting family of products, 'pseudodipeptides. ' Int. J. Cosmet. Sci. 2000, 22, 361-370. [CrossRef] [PubMed]

116. Poli, G.; Schaur, R.J.; Siems, W.G.; Leonarduzzi, G. 4-Hydroxynonenal: A membrane lipid oxidation product of medicinal interest. Med. Res. Rev. 2008, 28, 569-631. [CrossRef]

117. Shoeb, M.; Ansari, N.; Srivastava, S.; Ramana, K. 4-Hydroxynonenal in the Pathogenesis and Progression of Human Diseases. Curr. Med. Chem. 2013, 21, 230-237. [CrossRef]

118. Schaur, R.; Siems, W.; Bresgen, N.; Eckl, P. 4-Hydroxy-nonenal-A Bioactive Lipid Peroxidation Product. Biomolecules 2015, 5, 2247-2337. [CrossRef]

119. Barski, O.A.; Xie, Z.; Baba, S.P.; Sithu, S.D.; Agarwal, A.; Cai, J.; Bhatnagar, A.; Srivastava, S. Dietary Carnosine Prevents Early Atherosclerotic Lesion Formation in Apolipoprotein E-Null Mice. Arterioscler. Thromb. Vasc. Biol. 2013, 33, 1162-1170. [CrossRef] [PubMed]

120. Frohnert, B.I.; Sinaiko, A.R.; Serrot, F.J.; Foncea, R.E.; Moran, A.; Ikramuddin, S.; Choudry, U.; Bernlohr, D.A. Increased Adipose Protein Carbonylation in Human Obesity. Obesity 2011, 19, 1735-1741. [CrossRef] [PubMed] 
121. Toyokuni, S.; Yamada, S.; Kashima, M.; Ihara, Y.; Yamada, Y.; Tanaka, T.; Hiai, H.; Seino, Y.; Uchida, K. Serum 4-Hydroxy-2Nonenal-Modified Albumin Is Elevated in Patients with Type 2 Diabetes Mellitus. Antioxid. Redox Signal. 2000, 2, $681-685$. [CrossRef]

122. Katunga, L.A.; Gudimella, P.; Efird, J.T.; Abernathy, S.; Mattox, T.A.; Beatty, C.; Darden, T.M.; Thayne, K.A.; Alwair, H.; Kypson, A.P.; et al. Obesity in a model of gpx4 haploinsufficiency uncovers a causal role for lipid-derived aldehydes in human metabolic disease and cardiomyopathy. Mol. Metab. 2015, 4, 493-506. [CrossRef]

123. Anderson, E.J.; Vistoli, G.; Katunga, L.A.; Funai, K.; Regazzoni, L.; Monroe, T.B.; Gilardoni, E.; Cannizzaro, L.; Colzani, M.; De Maddis, D.; et al. A carnosine analog mitigates metabolic disorders of obesity by reducing carbonyl stress. J. Clin. Invest. 2018, 128, 5280-5293. [CrossRef]

124. Caruso, G.; Fresta, C.; Musso, N.; Giambirtone, M.; Grasso, M.; Spampinato, S.; Merlo, S.; Drago, F.; Lazzarino, G.; Sortino, M.; et al. Carnosine Prevents A $\beta$-Induced Oxidative Stress and Inflammation in Microglial Cells: A Key Role of TGF- $\beta 1$. Cells 2019, 8, 64. [CrossRef]

125. Onufriev, M.V.; Potanova, G.I.; Silaeva, S.A.; Nikolaev, A.I. Carnosine as a stimulator of cytotoxic and phagocytic function of peritoneal macrophages. Biokhimiia 1992, 57, 1352-1359. [PubMed]

126. Tanaka, K.-I.; Sugizaki, T.; Kanda, Y.; Tamura, F.; Niino, T.; Kawahara, M. Preventive Effects of Carnosine on Lipopolysaccharideinduced Lung Injury. Sci. Rep. 2017, 7, 42813. [CrossRef]

127. Tsai, S.-J.; Kuo, W.-W.; Liu, W.-H.; Yin, M.-C. Antioxidative and Anti-Inflammatory Protection from Carnosine in the Striatum of MPTP-Treated Mice. J. Agric. Food Chem. 2010, 58, 11510-11516. [CrossRef] [PubMed]

128. Invernizzi, P.L.; Venerando, B.; Di Pierro, F.; Saronni, S.; Papini, N. Effects of Carnosine and Beta-Alanine Ingestion on Anaerobic Sprint Performance and Peripheral Blood Mononuclear Cell Interleukin-6 and -10 Gene Expression. Adv. Phys. Educ. 2013, 03, 197-204. [CrossRef]

129. Houjeghani, S.; Kheirouri, S.; Faraji, E.; Jafarabadi, M.A. L-Carnosine supplementation attenuated fasting glucose, triglycerides, advanced glycation end products, and tumor necrosis factor- $\alpha$ levels in patients with type 2 diabetes: A double-blind placebocontrolled randomized clinical trial. Nutr. Res. 2018, 49, 96-106. [CrossRef]

130. Katakura, Y.; Totsuka, M.; Imabayashi, E.; Matsuda, H.; Hisatsune, T. Anserine/Carnosine Supplementation Suppresses the Expression of the Inflammatory Chemokine CCL24 in Peripheral Blood Mononuclear Cells from Elderly People. Nutrients 2017, 9, 1199. [CrossRef] [PubMed]

131. Hasanein, P.; Felegari, Z. Chelating effects of carnosine in ameliorating nickel-induced nephrotoxicity in rats. Can. J. Physiol. Pharmacol. 2017, 95, 1426-1432. [CrossRef] [PubMed]

132. Navarro, J.F.; Mora, C. Diabetes, Inflammation, Proinflammatory Cytokines, and Diabetic Nephropathy. Sci. World J. 2006, 6, 908-917. [CrossRef]

133. Stentz, F.B.; Umpierrez, G.E.; Cuervo, R.; Kitabchi, A.E. Proinflammatory Cytokines, Markers of Cardiovascular Risks, Oxidative Stress, and Lipid Peroxidation in Patients With Hyperglycemic Crises. Diabetes 2004, 53, 2079-2086. [CrossRef]

134. Guest, C.B.; Park, M.J.; Johnson, D.R.; Freund, G.G. The implication of proinflammatory cytokines in type 2 diabetes. Front. Biosci. 2008, Volume, 5187. [CrossRef]

135. Lee, Y.; Hsu, C.; Lin, M.; Liu, K.; Yin, M. Histidine and carnosine delay diabetic deterioration in mice and protect human low density lipoprotein against oxidation and glycation. Eur. J. Pharmacol. 2005, 513, 145-150. [CrossRef] [PubMed]

136. de Courten, B.; Jakubova, M.; de Courten, M.P.; Kukurova, I.J.; Vallova, S.; Krumpolec, P.; Valkovic, L.; Kurdiova, T.; Garzon, D.; Barbaresi, S.; et al. Effects of carnosine supplementation on glucose metabolism: Pilot clinical trial. Obesity 2016, 24, 1027-1034. [CrossRef] [PubMed]

137. Baye, E.; Ukropec, J.; de Courten, M.P.; Vallova, S.; Krumpolec, P.; Kurdiova, T.; Aldini, G.; Ukropcova, B.; de Courten, B. Effect of carnosine supplementation on the plasma lipidome in overweight and obese adults: A pilot randomised controlled trial. Sci. Rep. 2017, 7, 17458. [CrossRef]

138. Baye, E.; Ukropec, J.; de Courten, M.P.J.; Kurdiova, T.; Krumpolec, P.; Fernández-Real, J.-M.; Aldini, G.; Ukropcova, B.; de Courten, B. Carnosine supplementation reduces plasma soluble transferrin receptor in healthy overweight or obese individuals: A pilot randomised trial. Amino Acids 2019, 51, 73-81. [CrossRef] [PubMed]

139. Katsanos, K.H.; Papadakis, K.A. Inflammatory Bowel Disease: Updates on Molecular Targets for Biologics. Gut Liver 2017, 11, 455-463. [CrossRef]

140. Son, D.O.; Satsu, H.; Kiso, Y.; Shimizu, M. Characterization of carnosine uptake and its physiological function in human intestinal epithelial Caco-2 cells. BioFactors 2004, 21, 395-398. [CrossRef]

141. Son, D.O.; Satsu, H.; Kiso, Y.; Totsuka, M.; Shimizu, M. Inhibitory effect of carnosine on interleukin-8 production in intestinal epithelial cells through translational regulation. Cytokine 2008, 42, 265-276. [CrossRef]

142. Hisamatsu, T.; Ono, N.; Imaizumi, A.; Mori, M.; Suzuki, H.; Uo, M.; Hashimoto, M.; Naganuma, M.; Matsuoka, K.; Mizuno, S.; et al. Decreased Plasma Histidine Level Predicts Risk of Relapse in Patients with Ulcerative Colitis in Remission. PLoS One 2015, 10, e0140716. [CrossRef]

143. Liu, W.; Liu, T.; Yin, M. Beneficial effects of histidine and carnosine on ethanol-induced chronic liver injury. Food Chem. Toxicol. 2008, 46, 1503-1509. [CrossRef]

144. Yan, S.; Wu, S.; Yin, M.; Chen, H.; Chen, H. Protective Effects from Carnosine and Histidine on Acetaminophen-Induced Liver Injury. J. Food Sci. 2009, 74, H259-H265. [CrossRef] 
145. Hisatsune, T.; Kaneko, J.; Kurashige, H.; Cao, Y.; Satsu, H.; Totsuka, M.; Katakura, Y.; Imabayashi, E.; Matsuda, H. Effect of Anserine/Carnosine Supplementation on Verbal Episodic Memory in Elderly People. J. Alzheimer's Dis. 2015, 50, 149-159. [CrossRef]

146. Baye, E.; Menon, K.; de Courten, M.P.; Earnest, A.; Cameron, J.; de Courten, B. Does supplementation with carnosine improve cardiometabolic health and cognitive function in patients with pre-diabetes and type 2 diabetes? study protocol for a randomised, double-blind, placebo-controlled trial. BMJ Open 2017, 7, e017691. [CrossRef]

147. Sahin, S.; Burukoglu Donmez, D. Effects of Carnosine (Beta-Alanyl-L-Histidine) in an Experimental Rat Model of Acute Kidney Injury Due to Septic Shock. Med. Sci. Monit. 2018, 24, 305-316. [CrossRef] [PubMed]

148. Case, J.; Khan, S.; Khalid, R.; Khan, A. Epidemiology of Acute Kidney Injury in the Intensive Care Unit. Crit. Care Res. Pract. 2013, 2013, 1-9. [CrossRef]

149. Sun, C.; Wu, Q.; Zhang, X.; He, Q.; Zhao, H. Mechanistic Evaluation of the Protective Effect of Carnosine on Acute Lung Injury in Sepsis Rats. Pharmacology 2017, 100, 292-300. [CrossRef] [PubMed]

150. Furst, T.; Massaro, A.; Miller, C.; Williams, B.T.; LaMacchia, Z.M.; Horvath, P.J. $\beta$-Alanine supplementation increased physical performance and improved executive function following endurance exercise in middle aged individuals. J. Int. Soc. Sports Nutr. 2018, 15, 32. [CrossRef] [PubMed]

151. Glenn, J.M.; Gray, M.; Stewart, R.; Moyen, N.E.; Kavouras, S.A.; DiBrezzo, R.; Turner, R.; Baum, J. Incremental effects of 28 days of beta-alanine supplementation on high-intensity cycling performance and blood lactate in masters female cyclists. Amino Acids 2015, 47, 2593-2600. [CrossRef]

152. Glenn, J.M.; Gray, M.; Stewart, R.W.; Moyen, N.E.; Kavouras, S.A.; DiBrezzo, R.; Turner, R.; Baum, J.I.; Stone, M.S. Effects of 28-Day Beta-Alanine Supplementation on Isokinetic Exercise Performance and Body Composition in Female Masters Athletes. J. Strength Cond. Res. 2016, 30, 200-207. [CrossRef]

153. del Favero, S.; Roschel, H.; Solis, M.Y.; Hayashi, A.P.; Artioli, G.G.; Otaduy, M.C.; Benatti, F.B.; Harris, R.C.; Wise, J.A.; Leite, C.C.; et al. Beta-alanine (Carnosyn ${ }^{\mathrm{TM}}$ ) supplementation in elderly subjects (60-80 years): Effects on muscle carnosine content and physical capacity. Amino Acids 2012, 43, 49-56. [CrossRef] [PubMed]

154. Small, B.J.; Rawson, K.S.; Martin, C.; Eisel, S.L.; Sanberg, C.D.; McEvoy, C.L.; Sanberg, P.R.; Shytle, R.D.; Tan, J.; Bickford, P.C. Nutraceutical Intervention Improves Older Adults' Cognitive Functioning. Rejuvenation Res. 2014, 17, 27-32. [CrossRef]

155. Caruso, G.; Godos, J.; Castellano, S.; Micek, A.; Murabito, P.; Galvano, F.; Ferri, R.; Grosso, G.; Caraci, F. The Therapeutic Potential of Carnosine/Anserine Supplementation against Cognitive Decline: A Systematic Review with Meta-Analysis. Biomedicines 2021, 9, 253. [CrossRef] [PubMed]

156. Xie, Z.; Baba, S.P.; Sweeney, B.R.; Barski, O.A. Detoxification of aldehydes by histidine-containing dipeptides: From chemistry to clinical implications. Chem. Biol. Interact. 2013, 202, 288-297. [CrossRef]

157. Charoensin, S.; Laopaiboon, B.; Boonkum, W.; Phetcharaburanin, J.; Villareal, M.O.; Isoda, H.; Duangjinda, M. Thai Native Chicken as a Potential Functional Meat Source Rich in Anserine, Anserine/Carnosine, and Antioxidant Substances. Animals 2021, 11, 902. [CrossRef]

158. Kai, S.; Watanabe, G.; Kubota, M.; Kadowaki, M.; Fujimura, S. Effect of dietary histidine on contents of carnosine and anserine in muscles of broilers. Anim. Sci. J. 2015, 86, 541-546. [CrossRef] [PubMed]

159. Tomonaga, S.; Matsumoto, M.; Furuse, M. $\beta$-Alanine Enhances Brain and Muscle Carnosine Levels in Broiler Chicks. J. Poult. Sci. 2012, 49, 308-312. [CrossRef]

160. Kralik, G.; Kralik, Z.; Djurkin Kušec, I.; Škrtić, Z.; Kralik, I. Influence of Dietary Histidine, Hybrid Line and Gender on Chicken Meat Quality and Carnosine Concentration. J. Poult. Sci. 2015, 52, 295-303. [CrossRef]

161. Kralik, G.; Sak-Bosnar, M.; Kralik, Z.; Galović, O.; Grčević, M.; Kralik, I. Effect of $\beta$-alanine and L-histidine on concentration of carnosine in muscle tissue and oxidative stability of chicken meat. Poljoprivreda 2015, 21, 190-194. [CrossRef]

162. Haug, A.; R $\oslash$ dbotten, R.; Mydland, L.T.; Christophersen, O.A. Increased broiler muscle carnosine and anserine following histidine supplementation of commercial broiler feed concentrate. Acta Agric. Scand. Sect. A Anim. Sci. 2008, 58, 71-77. [CrossRef]

163. Harris, R.C.; Tallon, M.J.; Dunnett, M.; Boobis, L.; Coakley, J.; Kim, H.J.; Fallowfield, J.L.; Hill, C.A.; Sale, C.; Wise, J.A. The absorption of orally supplied $\beta$-alanine and its effect on muscle carnosine synthesis in human vastus lateralis. Amino Acids 2006, 30, 279-289. [CrossRef]

164. Kopec, W.; Jamroz, D.; Wiliczkiewicz, A.; Biazik, E.; Pudlo, A.; Korzeniowska, M.; Hikawczuk, T.; Skiba, T. Antioxidative Characteristics of Chicken Breast Meat and Blood after Diet Supplementation with Carnosine, L-histidine, and $\beta$-alanine. Antioxidants 2020, 9, 1093. [CrossRef]

165. Qi, B.; Wang, J.; Ma, Y.; Wu, S.; Qi, G.; Zhang, H. Effect of dietary $\beta$-alanine supplementation on growth performance, meat quality, carnosine content, and gene expression of carnosine-related enzymes in broilers. Poult. Sci. 2018, 97, 1220-1228. [CrossRef] [PubMed]

166. Perim, P.; Marticorena, F.M.; Ribeiro, F.; Barreto, G.; Gobbi, N.; Kerksick, C.; Dolan, E.; Saunders, B. Can the Skeletal Muscle Carnosine Response to Beta-Alanine Supplementation Be Optimized? Front. Nutr. 2019, 6. [CrossRef]

167. Cong, J.; Zhang, L.; Li, J.; Wang, S.; Gao, F.; Zhou, G. Effects of dietary supplementation with carnosine on growth performance, meat quality, antioxidant capacity and muscle fiber characteristics in broiler chickens. J. Sci. Food Agric. 2017, 97, 3733-3741. [CrossRef] [PubMed] 
168. Kralik, G.; Sak-Bosnar, M.; Grčević, M.; Kralik, Z. Effect of Amino Acids on Growth Performance, Carcass Characteristics, Meat Quality, and Carnosine Concentration in Broiler Chickens. J. Poult. Sci. 2018, 55, 239-248. [CrossRef]

169. Soyer, A.; Özalp, B.; Dalmış, Ü.; Bilgin, V. Effects of freezing temperature and duration of frozen storage on lipid and protein oxidation in chicken meat. Food Chem. 2010, 120, 1025-1030. [CrossRef]

170. Cong, J.; Zhang, L.; Li, J.; Wang, S.; Gao, F.; Zhou, G. Effects of dietary supplementation with carnosine on meat quality and antioxidant capacity in broiler chickens. Br. Poult. Sci. 2017, 58, 69-75. [CrossRef] [PubMed]

171. Petersmann, A.; Müller-Wieland, D.; Müller, U.A.; Landgraf, R.; Nauck, M.; Freckmann, G.; Heinemann, L.; Schleicher, E. Definition, Classification and Diagnosis of Diabetes Mellitus. Exp. Clin. Endocrinol. Diabetes 2019, 127, S1-S7. [CrossRef]

172. Soliman, K.M.; Mohamed, A.M.; Metwally, N.S. Attenuation of Some Metabolic Deteriorations Induced by Diabetes Mellitus Using Carnosine. J. Appl. Sci. 2007, 7, 2252-2260. [CrossRef]

173. Kubomura, D.; Matahira, Y.; Nagai, K.; Niijima, A. Effect of anserine ingestion on hyperglycemia and the autonomic nerves in rats and humans. Nutr. Neurosci. 2010, 13, 183-188. [CrossRef]

174. Sauerhofer, S.; Yuan, G.; Braun, G.S.; Deinzer, M.; Neumaier, M.; Gretz, N.; Floege, J.; Kriz, W.; van der Woude, F.; Moeller, M.J L-Carnosine, a Substrate of Carnosinase-1, Influences Glucose Metabolism. Diabetes 2007, 56, 2425-2432. [CrossRef] [PubMed]

175. Al-Sawalha, N.A.; Alshogran, O.Y.; Awawdeh, M.S.; Almomani, B.A. The effects of l-Carnosine on development of metabolic syndrome in rats. Life Sci. 2019, 237, 116905. [CrossRef]

176. Albrecht, T.; Schilperoort, M.; Zhang, S.; Braun, J.D.; Qiu, J.; Rodriguez, A.; Pastene, D.O.; Krämer, B.K.; Köppel, H.; Baelde, H.; et al. Carnosine Attenuates the Development of both Type 2 Diabetes and Diabetic Nephropathy in BTBR ob/ob Mice. Sci. Rep. 2017, 7, 44492. [CrossRef] [PubMed]

177. Peters, V.; Schmitt, C.P.; Zschocke, J.; Gross, M.-L.; Brismar, K.; Forsberg, E. Carnosine treatment largely prevents alterations of renal carnosine metabolism in diabetic mice. Amino Acids 2012, 42, 2411-2416. [CrossRef]

178. Janssen, B.; Hohenadel, D.; Brinkkoetter, P.; Peters, V.; Rind, N.; Fischer, C.; Rychlik, I.; Cerna, M.; Romzova, M.; de Heer, E.; et al. Carnosine as a Protective Factor in Diabetic Nephropathy: Association With a Leucine Repeat of the Carnosinase Gene CNDP1. Diabetes 2005, 54, 2320-2327. [CrossRef]

179. Fatih Aydın, A.; Küçükgergin, C.; Bingül, İ.; Doğan-Ekici, I.; Doğru-Abbasoğlu, S.; Uysal, M. Effect of Carnosine on Renal Function, Oxidation and Glycation Products in the Kidneys of High-Fat Diet/Streptozotocin-Induced Diabetic Rats. Exp. Clin. Endocrinol. Diabetes 2017, 125, 282-289. [CrossRef]

180. Forsberg, E.A.; Botusan, I.R.; Wang, J.; Peters, V.; Ansurudeen, I.; Brismar, K.; Catrina, S.B. Carnosine decreases IGFBP1 production in $\mathrm{db} / \mathrm{db}$ mice through suppression of HIF-1. J. Endocrinol. 2015, 225, 159-167. [CrossRef] [PubMed]

181. Karkabounas, S.; Papadopoulos, N.; Anastasiadou, C.; Gubili, C.; Peschos, D.; Daskalou, T.; Fikioris, N.; Simos, Y.V.; Kontargiris, E.; Gianakopoulos, X.; et al. Effects of $\alpha$-Lipoic Acid, Carnosine, and Thiamine Supplementation in Obese Patients with Type 2 Diabetes Mellitus: A Randomized, Double-Blind Study. J. Med. Food 2018, 21, 1197-1203. [CrossRef]

182. Peng, W.; Mao, P.; Liu, L.; Chen, K.; Zhong, Y.; Xia, W.; Guo, Q.; Tan, S.C.; Rahmani, J.; Kord Varkaneh, H.; et al. Effect of carnosine supplementation on lipid profile, fasting blood glucose, $\mathrm{HbA1C}$ and insulin resistance: A systematic review and meta-analysis of long-term randomized controlled trials. Complement. Ther. Med. 2020, 48, 102241. [CrossRef]

183. Caruso, G.; Fresta, C.G.; Grasso, M.; Santangelo, R.; Lazzarino, G.; Lunte, S.M.; Caraci, F. Inflammation as the Common Biological Link Between Depression and Cardiovascular Diseases: Can Carnosine Exert a Protective Role? Curr. Med. Chem. 2020, 27, 1782-1800. [CrossRef]

184. Gimbrone, M.A.; García-Cardeña, G. Endothelial Cell Dysfunction and the Pathobiology of Atherosclerosis. Circ. Res. 2016, 118, 620-636. [CrossRef]

185. Yang, X.; Li, Y.; Li, Y.; Ren, X.; Zhang, X.; Hu, D.; Gao, Y.; Xing, Y.; Shang, H. Oxidative Stress-Mediated Atherosclerosis: Mechanisms and Therapies. Front. Physiol. 2017, 8. [CrossRef]

186. Caruso, G.; Fresta, C.G.; Fidilio, A.; O’Donnell, F.; Musso, N.; Lazzarino, G.; Grasso, M.; Amorini, A.M.; Tascedda, F.; Bucolo, C.; et al. Carnosine Decreases PMA-Induced Oxidative Stress and Inflammation in Murine Macrophages. Antioxidants 2019, 8, 281. [CrossRef] [PubMed]

187. Nelson, M.-A.M.; Builta, Z.J.; Monroe, T.B.; Doorn, J.A.; Anderson, E.J. Biochemical characterization of the catecholaldehyde reactivity of 1-carnosine and its therapeutic potential in human myocardium. Amino Acids 2019, 51, 97-102. [CrossRef]

188. Lombardi, C.; Carubelli, V.; Lazzarini, V.; Vizzardi, E.; Bordonali, T.; Ciccarese, C.; Castrini, A.I.; Dei Cas, A.; Nodari, S.; Metra, M. Effects of oral administration of orodispersible levo-carnosine on quality of life and exercise performance in patients with chronic heart failure. Nutrition 2015, 31, 72-78. [CrossRef] [PubMed]

189. Kumral, A.; Giriş, M.; Soluk-Tekkeşin, M.; Olgaç, V.; Doğru-Abbasoğlu, S.; Türkoğlu, Ü.; Uysal, M. Beneficial effects of carnosine and carnosine plus vitamin $\mathrm{E}$ treatments on doxorubicin-induced oxidative stress and cardiac, hepatic, and renal toxicity in rats. Hum. Exp. Toxicol. 2016, 35, 635-643. [CrossRef]

190. Gan, L.; Johnson, J.A. Oxidative damage and the Nrf2-ARE pathway in neurodegenerative diseases. Biochim. Biophys. Acta Mol. Basis Dis. 2014, 1842, 1208-1218. [CrossRef]

191. Bhat, A.H.; Dar, K.B.; Anees, S.; Zargar, M.A.; Masood, A.; Sofi, M.A.; Ganie, S.A. Oxidative stress, mitochondrial dysfunction and neurodegenerative diseases; a mechanistic insight. Biomed. Pharmacother. 2015, 74, 101-110. [CrossRef] [PubMed]

192. Cahill-Smith, S.; Li, J.-M. Oxidative stress, redox signalling and endothelial dysfunction in ageing-related neurodegenerative diseases: A role of NADPH oxidase 2. Br. J. Clin. Pharmacol. 2014, 78, 441-453. [CrossRef] 
193. Cojocaru, I.M.; Cojocaru, M.; Sapira, V.; Ionescu, A. Evaluation of oxidative stress in patients with acute ischemic stroke. Rom. J. Intern. Med. 2013, 51, 97-106.

194. Fendri, C.; Mechri, A.; Khiari, G.; Othman, A.; Kerkeni, A.; Gaha, L. Implication du stress oxydant dans la physiopathologie de la schizophrénie: Revue de la literature. Encephale. 2006, 32, 244-252. [CrossRef]

195. Maria Michel, T.; Pulschen, D.; Thome, J. The Role of Oxidative Stress in Depressive Disorders. Curr. Pharm. Des. 2012, 18, 5890-5899. [CrossRef]

196. Fedorova, T.N.; Belyaev, M.S.; Trunova, O.A.; Gnezditsky, V.V.; Maximova, M.Y.; Boldyrev, A.A. Neuropeptide carnosine increases stability of lipoproteins and red blood cells as well as efficiency of immune competent system in patients with chronic discirculatory encephalopathy. Biochem. Suppl. Ser. A Membr. Cell Biol. 2009, 3, 62-65. [CrossRef]

197. Boldyrev, A.; Fedorova, T.; Stepanova, M.; Dobrotvorskaya, I.; Kozlova, E.; Boldanova, N.; Bagyeva, G.; Ivanova-Smolenskaya, I.; Illarioshkin, S. Carnisone Increases Efficiency of DOPA Therapy of Parkinson's Disease: A Pilot Study. Rejuvenation Res. 2008, 11, 821-827. [CrossRef]

198. Davis, C.K.; Laud, P.J.; Bahor, Z.; Rajanikant, G.; Majid, A. Systematic review and stratified meta-analysis of the efficacy of carnosine in animal models of ischemic stroke. J. Cereb. Blood Flow Metab. 2016, 36, 1686-1694. [CrossRef]

199. Yasuhara, T.; Hara, K.; Maki, M.; Masuda, T.; Sanberg, C.D.; Sanberg, P.R.; Bickford, P.C.; Borlongan, C.V. Dietary Supplementation Exerts Neuroprotective Effects in Ischemic Stroke Model. Rejuvenation Res. 2008, 11, 201-214. [CrossRef]

200. Wang, A.; Ma, Q.; Wang, X.; Xu, G. Protective effects of beef decoction rich in carnosine on cerebral ischemia injury by permanent middle cerebral artery occlusion in rats. Exp. Ther. Med. 2017. [CrossRef]

201. Pekcetin, C.; Kiray, M.; Ergur, B.; Tugyan, K.; Bagriyanik, H.; Erbil, G.; Baykara, B.; Camsari, U. Carnosine attenuates oxidative stress and apoptosis in transient cerebral ischemia in rats. Acta Biol. Hung. 2009, 60, 137-148. [CrossRef]

202. Wang, J.-P.; Yang, Z.-T.; Liu, C.; He, Y.-H.; Zhao, S.-S. L-carnosine inhibits neuronal cell apoptosis through signal transducer and activator of transcription 3 signaling pathway after acute focal cerebral ischemia. Brain Res. 2013, 1507, 125-133. [CrossRef]

203. Min, J.; Senut, M.-C.; Rajanikant, K.; Greenberg, E.; Bandagi, R.; Zemke, D.; Mousa, A.; Kassab, M.; Farooq, M.U.; Gupta, R.; et al. Differential neuroprotective effects of carnosine, anserine, and $\mathrm{N}$-acetyl carnosine against permanent focal ischemia. J. Neurosci. Res. 2008, 86, 2984-2991. [CrossRef]

204. Dichter, M.A. Emerging Insights Into Mechanisms of Epilepsy: Implications for New Antiepileptic Drug Development. Epilepsia 1994, 35, S51-S57. [CrossRef] [PubMed]

205. Gietzen, D.W.; Lindström, S.H.; Sharp, J.W.; Teh, P.S.; Donovan, M.J. Indispensable Amino Acid-Deficient Diets Induce Seizures in Ketogenic Diet-Fed Rodents, Demonstrating a Role for Amino Acid Balance in Dietary Treatments for Epilepsy. J. Nutr. 2018, 148, 480-489. [CrossRef] [PubMed]

206. Qi, Z.; Yu, X.; Xu, P.; Hao, Y.; Pan, X.; Zhang, C. L-Homocarnosine, l-carnosine, and anserine attenuate brain oxidative damage in a pentylenetetrazole-induced epilepsy model of ovariectomized rats. 3 Biotech 2018, 8, 363. [CrossRef] [PubMed]

207. Wu, X.; Ding, M.; Zhu-Ge, Z.-B.; Zhu, Y.-Y.; Jin, C.; Chen, Z. Carnosine, a precursor of histidine, ameliorates pentylenetetrazoleinduced kindled seizures in rat. Neurosci. Lett. 2006, 400, 146-149. [CrossRef]

208. Zhu, Y.-Y.; Zhu-Ge, Z.-B.; Wu, D.-C.; Wang, S.; Liu, L.-Y.; Ohtsu, H.; Chen, Z. Carnosine inhibits pentylenetetrazol-induced seizures by histaminergic mechanisms in histidine decarboxylase knock-out mice. Neurosci. Lett. 2007, 416, 211-216. [CrossRef]

209. Kozan, R.; Sefil, F.; Bağırıc1, F. Anticonvulsant effect of carnosine on penicillin-induced epileptiform activity in rats. Brain Res. 2008, 1239, 249-255. [CrossRef]

210. Jin, H.-B.; Li, B.; Cu, J.; Cheng, J.-S.; Yang, R. Electro-acupuncture improves epileptic seizures induced by kainic acid in taurine-depletion rats. Acupunct. Electrother. Res. 2005, 30, 207-217. [CrossRef]

211. Kamiński, R.M.; Żółkowska, D.; Kozicka, M.; Kleinrok, Z.; Czuczwar, S.J. L-Histidine is a beneficial adjuvant for antiepileptic drugs against maximal electroshock-induced seizures in mice. Amino Acids 2004, 26, 85-89. [CrossRef]

212. Feng, Z.; Zheng, X.; Wang, J. Effects of carnosine on the evoked potentials in hippocampal CA1 region. J. Zhejiang Univ. Sci. B 2009, 10, 505-511. [CrossRef]

213. Guiotto, A.; Calderan, A.; Ruzza, P.; Borin, G. Carnosine and Carnosine-Related Antioxidants: A Review. Curr. Med. Chem. 2005, 12, 2293-2315. [CrossRef]

214. Koffie, R.M.; Hyman, B.T.; Spires-Jones, T.L. Alzheimer's disease: Synapses gone cold. Mol. Neurodegener. 2011, 6, 63. [CrossRef]

215. Pan, X.; Green, B.D. Temporal Effects of Neuron-specific beta-secretase 1 (BACE1) Knock-in on the Mouse Brain Metabolome: Implications for Alzheimer's Disease. Neuroscience 2019, 397, 138-146. [CrossRef]

216. Sase, A.; Dahanayaka, S.; Höger, H.; Wu, G.; Lubec, G. Changes of hippocampal beta-alanine and citrulline levels are paralleling early and late phase of retrieval in the Morris Water Maze. Behav. Brain Res. 2013, 249, 104-108. [CrossRef] [PubMed]

217. Kaneko, J.; Enya, A.; Enomoto, K.; Ding, Q.; Hisatsune, T. Anserine (beta-alanyl-3-methyl-L-histidine) improves neurovascularunit dysfunction and spatial memory in aged AßPPswe/PSEN1dE9 Alzheimer's-model mice. Sci. Rep. 2017, 7, 12571. [CrossRef] [PubMed]

218. Corona, C.; Frazzini, V.; Silvestri, E.; Lattanzio, R.; La Sorda, R.; Piantelli, M.; Canzoniero, L.M.T.; Ciavardelli, D.; Rizzarelli, E.; Sensi, S.L. Effects of Dietary Supplementation of Carnosine on Mitochondrial Dysfunction, Amyloid Pathology, and Cognitive Deficits in 3xTg-AD Mice. PLoS ONE 2011, 6, e17971. [CrossRef] [PubMed] 
219. Fernandez-Busquets, X.; Ponce, J.; Bravo, R.; Arimon, M.; Martianez, T.; Gella, A.; Cladera, J.; Durany, N. Modulation of amyloid $\beta$ peptide1-42 cytotoxicity and aggregation in vitro by glucose and chondroitin sulfate. Curr. Alzheimer Res. 2010, 7, 428-438. [CrossRef]

220. Loske, C.; Gerdemann, A.; Schepl, W.; Wycislo, M.; Schinzel, R.; Palm, D.; Riederer, P.; Münch, G. Transition metal-mediated glycoxidation accelerates cross-linking of $\beta$-amyloid peptide. Eur. J. Biochem. 2000, 267, 4171-4178. [CrossRef]

221. Colín-Barenque, L.; Bizarro-Nevares, P.; González Villalva, A.; Pedraza-Chaverri, J.; Medina-Campos, O.N.; Jimenez-Martínez, R.; Rodríguez-Rangel, D.S.; Reséndiz, S.; Fortoul, T.I. Neuroprotective effect of carnosine in the olfactory bulb after vanadium inhalation in a mouse model. Int. J. Exp. Pathol. 2018, 99, 180-188. [CrossRef]

222. Kenneth Maiese; Zhao Zhong Chong; Yan Chen Shang Mechanistic Insights Into Diabetes Mellitus and Oxidative Stress. Curr. Med. Chem. 2007, 14, 1729-1738. [CrossRef]

223. Ma, J.; Chen, J.; Bo, S.; Lu, X.; Zhang, J. Protective effect of carnosine after chronic cerebral hypoperfusion possibly through suppressing astrocyte activation. Am. J. Transl. Res. 2015, 7, 2706-2715.

224. Hata, J.; Ohara, T.; Katakura, Y.; Shimizu, K.; Yamashita, S.; Yoshida, D.; Honda, T.; Hirakawa, Y.; Shibata, M.; Sakata, S.; et al. Association Between Serum $\beta$-Alanine and Risk of Dementia. Am. J. Epidemiol. 2019, 188, 1637-1645. [CrossRef]

225. Masuoka, N.; Yoshimine, C.; Hori, M.; Tanaka, M.; Asada, T.; Abe, K.; Hisatsune, T. Effects of Anserine/Carnosine Supplementation on Mild Cognitive Impairment with APOE4. Nutrients 2019, 11, 1626. [CrossRef] [PubMed]

226. Masuoka, N.; Lei, C.; Li, H.; Inamura, N.; Shiotani, S.; Yanai, N.; Sato, K.; Sakurai, K.; Hisatsune, T. Anserine, HClO-scavenger, protected against cognitive decline in individuals with mild cognitive impairment. Aging 2021, 13, 1729-1741. [CrossRef]

227. Cornelli, U. Treatment of Alzheimer's Disease with a Cholinesterase Inhibitor Combined with Antioxidants. Neurodegener. Dis. 2010, 7, 193-202. [CrossRef]

228. Rybakova, Y.S.; Boldyrev, A.A. Effect of Carnosine and Related Compounds on Proliferation of Cultured Rat Pheochromocytoma PC-12 Cells. Bull. Exp. Biol. Med. 2012, 154, 136-140. [CrossRef] [PubMed]

229. Oppermann, H.; Schnabel, L.; Meixensberger, J.; Gaunitz, F. Pyruvate attenuates the anti-neoplastic effect of carnosine independently from oxidative phosphorylation. Oncotarget 2016, 7, 85848-85860. [CrossRef]

230. Renner, C.; Asperger, A.; Seyffarth, A.; Meixensberger, J.; Gebhardt, R.; Gaunitz, F. Carnosine inhibits ATP production in cells from malignant glioma. Neurol. Res. 2010, 32, 101-105. [CrossRef]

231. Hipkiss, A.R.; Gaunitz, F. Inhibition of tumour cell growth by carnosine: Some possible mechanisms. Amino Acids 2014, 46, 327-337. [CrossRef] [PubMed]

232. Oppermann, H.; Faust, H.; Yamanishi, U.; Meixensberger, J.; Gaunitz, F. Carnosine inhibits glioblastoma growth independent from PI3K/Akt/mTOR signaling. PLoS ONE 2019, 14, e0218972. [CrossRef]

233. Hwang, B.; Shin, S.-S.; Song, J.-H.; Choi, Y.H.; Kim, W.-J.; Moon, S.-K. Carnosine exerts antitumor activity against bladder cancers in vitro and in vivo via suppression of angiogenesis. J. Nutr. Biochem. 2019, 74, 108230. [CrossRef]

234. WU, C.-C.; LAI, P.-Y.; HSIEH, S.; CHENG, C.-C.; HSIEH, S.-L. Suppression of Carnosine on Adhesion and Extravasation of Human Colorectal Cancer Cells. Anticancer Res. 2019, 39, 6135-6144. [CrossRef]

235. Iovine, B.; Oliviero, G.; Garofalo, M.; Orefice, M.; Nocella, F.; Borbone, N.; Piccialli, V.; Centore, R.; Mazzone, M.; Piccialli, G.; et al. The Anti-Proliferative Effect of L-Carnosine Correlates with a Decreased Expression of Hypoxia Inducible Factor 1 alpha in Human Colon Cancer Cells. PLoS ONE 2014, 9, e96755. [CrossRef]

236. Iovine, B.; Guardia, F.; Irace, C.; Bevilacqua, M.A. L-carnosine dipeptide overcomes acquired resistance to 5-fluorouracil in HT29 human colon cancer cells via downregulation of HIF1-alpha and induction of apoptosis. Biochimie 2016, 127, 196-204. [CrossRef] [PubMed]

237. Mikuła-Pietrasik, J.; Książek, K. L-Carnosine Prevents the Pro-cancerogenic Activity of Senescent Peritoneal Mesothelium Towards Ovarian Cancer Cells. Anticancer Res. 2016, 36, 665-671.

238. Ignarro, L.J.; Napoli, C. Novel features of nitric oxide, endothelial nitric oxide synthase, and atherosclerosis. Curr. Diab. Rep. 2005, 5, 17-23. [CrossRef] [PubMed]

239. Alaghband-Zadeh, J.; Mehdizadeh, S.; Khan, N.S.; Farrell, A.O.; Bitensky, L.; Chayen, J. The natural substrate for nitric oxide synthase activity. Cell Biochem. Funct. 2001, 19, 277-280. [CrossRef] [PubMed]

240. Takahashi, S.; Nakashima, Y.; Toda, K. Carnosine Facilitates Nitric Oxide Production in Endothelial F-2 Cells. Biol. Pharm. Bull. 2009, 32, 1836-1839. [CrossRef]

241. Severina, I.S.; Bussygina, O.G.; Pyatakova, N.V. Carnosine as a regulator of soluble guanylate cyclase. Biochemistry 2000, 65, 783-788.

242. Nicoletti, V.G.; Santoro, A.M.; Grasso, G.; Vagliasindi, L.I.; Giuffrida, M.L.; Cuppari, C.; Purrello, V.S.; Stella, A.M.G.; Rizzarelli, E. Carnosine interaction with nitric oxide and astroglial cell protection. J. Neurosci. Res. 2007, 85, 2239-2245. [CrossRef]

243. O'Dowd, A.; O'Dowd, J.J.; Miller, D.J. The dipeptide carnosine constricts rabbit saphenous vein as a zinc complex apparently via a serotonergic receptor. J. Physiol. 1996, 495, 535-543. [CrossRef] [PubMed]

244. Ririe, D.G.; Roberts, P.R.; Shouse, M.N.; Zaloga, G.P. Vasodilatory actions of the dietary peptide carnosine. Nutrition 2000, 16, 168-172. [CrossRef]

245. Vanhoutte, P.M. Serotonin and the vascular wall. Int. J. Cardiol. 1987, 14, 189-203. [CrossRef] 
246. Nagai, K.; Tanida, M.; Niijima, A.; Tsuruoka, N.; Kiso, Y.; Horii, Y.; Shen, J.; Okumura, N. Role of l-carnosine in the control of blood glucose, blood pressure, thermogenesis, and lipolysis by autonomic nerves in rats: Involvement of the circadian clock and histamine. Amino Acids 2012, 43, 97-109. [CrossRef] [PubMed]

247. Mong, M.; Chao, C.; Yin, M. Histidine and carnosine alleviated hepatic steatosis in mice consumed high saturated fat diet. Eur. J. Pharmacol. 2011, 653, 82-88. [CrossRef]

248. Liu, Y.; Cotillard, A.; Vatier, C.; Bastard, J.-P.; Fellahi, S.; Stévant, M.; Allatif, O.; Langlois, C.; Bieuvelet, S.; Brochot, A.; et al. A Dietary Supplement Containing Cinnamon, Chromium and Carnosine Decreases Fasting Plasma Glucose and Increases Lean Mass in Overweight or Obese Pre-Diabetic Subjects: A Randomized, Placebo-Controlled Trial. PLoS ONE 2015, 10, e0138646. [CrossRef] [PubMed]

249. Versari, D.; Daghini, E.; Virdis, A.; Ghiadoni, L.; Taddei, S. Endothelial Dysfunction as a Target for Prevention of Cardiovascular Disease. Diabetes Care 2009, 32, S314-S321. [CrossRef]

250. Ihara, H.; Kakihana, Y.; Yamakage, A.; Kai, K.; Shibata, T.; Nishida, M.; Yamada, K.; Uchida, K. 2-Oxo-histidine-containing dipeptides are functional oxidation products. J. Biol. Chem. 2019, 294, 1279-1289. [CrossRef]

251. Prokopieva, V.D.; Yarygina, E.G.; Bokhan, N.A.; Ivanova, S.A. Use of Carnosine for Oxidative Stress Reduction in Different Pathologies. Oxid. Med. Cell. Longev. 2016, 2016, 1-8. [CrossRef]

252. Daiber, A.; Steven, S.; Weber, A.; Shuvaev, V.V.; Muzykantov, V.R.; Laher, I.; Li, H.; Lamas, S.; Münzel, T. Targeting vascular (endothelial) dysfunction. Br. J. Pharmacol. 2017, 174, 1591-1619. [CrossRef] [PubMed] 